\title{
Compounds from African medicinal plants with activities against protozoal diseases: schistosomiasis, trypanosomiasis and leishmaniasis
}

Conrad V. Simoben ${ }^{\mathrm{a}}$, Fidele Ntie-Kang ${ }^{\mathrm{a}, \mathrm{b}^{*}}$, Sergi H. Akone ${ }^{\mathrm{c}, \mathrm{d}}$ and Wolfgang Sippl ${ }^{\mathrm{a}}$

An absolute configuration of $5 R$ seems to decrease activity of the compound<smiles>[R2]c1c(OC)c(=O)c2c(n1OC)C([R3])CC[C@]2([R3])C</smiles>

methoxy group bound to the $\mathrm{N}$-atom is important for activity

1. Introduction ....

2. Alkaloids ....

2.1. Naphthoisoquinolines ...

2.2. Aporphines ...

2.3. Quinones ...

2.4. Indoles and other alkaloids ...

3. Terpenoids ....

3.1. Sesquiterpenoids ....

3.2. Carvotacetone derivatives...

3.3. Diterpenoids ....

3.4. Triterpenoids ....

4. Other compound classes....

4.1. Amides...

4.2. Diarylhepanoids....

4.3. Benzophenones and xanthones...

4.4. Taccalonolides....

4.5. Quiniones and klaivanolide...

4.6. Flavonoids....

4.7. Phytosterols....

5. Conclusions ...

Acknowledgments ...

Conflicts of Interest ...

References ... 


\title{
Compounds from African medicinal plants with activities against protozoal diseases: schistosomiasis, trypanosomiasis and leishmaniasis
}

\author{
Conrad V. Simoben ${ }^{\mathrm{a}}$, Fidele Ntie-Kang ${ }^{\mathrm{a}, \mathrm{b}^{*}}$, Sergi H. Akone ${ }^{\mathrm{c}, \mathrm{d}}$ and Wolfgang Sippl ${ }^{\mathrm{a}}$ \\ ${ }^{a}$ Institute of Pharmacy, Martin-Luther University of Halle-Wittenberg, Wolfgang-Langenbeck-Str. 4, Halle (Saale) 06120, Germany. \\ ${ }^{b}$ Department of Chemistry, Faculty of Science, University of Buea, P.O. Box 63, Buea 00237, Cameroon. \\ ${ }^{c}$ Institute of Pharmaceutical Biology and Biotechnology, Heinrich-Heine-University, Universitaetsstrasse1, Geb. 26.23, Duesseldorf 40225, Germany. \\ ${ }^{d}$ Department of Chemistry, Faculty of Science, University of Douala, PO Box 24157, Douala 00237, Cameroon. \\ *Corresponding author (Email: ntiekfidele@gmail.com)
}

ARTICLE INFO

ABSTRACT

Article history:

Received

Revised

Accepted

Available online

Keywords:

African medicinal plants

Leishmaniasis

Natural products

Protozoal diseases

Schistosomiasis

Trypanosomiasis

\begin{abstract}
English abstract: Parasitic diseases continue represent a threat on a global scale, particularly among the poorest countries in the world. This is particularly because of the absence of vaccines, and in some cases, resistance against available drugs, currently being used for their treatment. In this review emphasis is laid on natural products and scaffolds from African medicinal plants (AMPs) for lead drug discovery and possible further development of drugs for the treatment of parasitic diseases. In the discussion, emphasis has been laid on alkaloids, terpenoids, quinones, flavonoids and narrower compound classes of compounds with micromolar range activities against Schistosoma, Trypanosoma and Leishmania species. Suggestions for future drug development from African medicinal plants have also been provided.
\end{abstract}

\section{Introduction}

Protozoa may be considered as microscopic, essentially single-celled, eukaryotic organisms that are free-living or parasitic (obtaining their food by eating other organisms or their products) in nature. Parasitic protozoal diseases continue to be a cause of considerable morbidity and mortality globally. ${ }^{1,2}$ Parasitic protozoal diseases include malaria, ${ }^{3,4}$ trypanosomiasis (African sleeping sickness and Chagas disease), ${ }^{5-7}$ leishmaniasis ${ }^{8}$ and schistosomiasis. ${ }^{9,10}$ They threaten almost one-third of the world's population, the most numerous incidents being recorded in over 100 Tropical and developing countries and territories, Figure 1. ${ }^{11,12}$ Malaria, for example, was reported by the WHO, to be responsible for approximately 214 million sickness cases and 438,000 deaths globally in $2017 .{ }^{13}$ The African region recorded the most death-related cases, especially amongst infants below the age of 5 and pregnant women. Schistosomiasis, caused by parasites of the Schistosoma genus are responsible for about 200 million sickness cases and about 280,000 death-related incidents annually worldwide. ${ }^{9,10,14}$ Only one drug (praziquantel) has been proven to be effective in the treatment of human schistosomiasis, with no vaccine available or in development so far. ${ }^{15-21}$ Serious concerns about drug selectivity and resistance were raised in 2013 when over 30 million people were treated in Sub-Saharan Africa. ${ }^{20}$ Moreover, observed resistance and reduced efficiency of praziquantel in laboratory strains have prompted the search for alternative therapeutic strategies. ${ }^{20-27}$

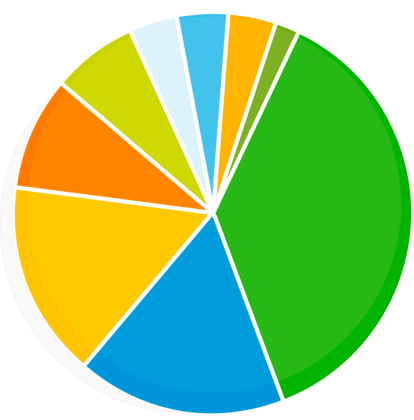

HIV/AIDS - 2\%
Injuries (post neonatal) - 4\%
Noncommunicable diseases (postneonatal) - 4\%
Measles - 4\%
Malaria - $7 \%$
Other infections and parasitic diseases - 9\%
*Diarrhoeal diseases (postneonatal) - $16 \%$
*Acute respitory infections (postneonatal) - 17\%
Neonatal deaths - 37\%

Fig. 1. Global statistics for disease burdens in 2017.

Trypanosomiasis, which represents several diseases caused by parasites of the genus Trypanosoma, is also of interest. ${ }^{5,27,29}$ This disease, which is much arguably the most important disease of man and domesticated animals, accounts for over 8 million reported annual cases globally, especially in the tropical regions of Latin America and Africa. ${ }^{30,31}$ Although the present number of cases seems negligible on a worldwide scale, great socioeconomic effects on the endemic areas by this disease are forecast if inadequate attention (both at the communal, national, and international levels) is not given.,29,32-34 Leishmaniasis is caused by parasites of the Leishmania type, which is also transmitted by certain types of sandflies..$^{35,36}$ The diseases are reported by the WHO to be responsible for about 1 million new cases leading to approximately 30,000 deaths annually on a global scale. The major cause is linked to environmental changes 
and affects mainly the very poor populations. ${ }^{37,38}$ These three diseases represent a real burden to the lives of millions of persons and their domesticated animals. The trio is capable of inflicting long-term disability and social stigmatisation, which can ultimately lead to a highly unproductive population and eventually result in economic loss and the slowdown of a country's development.

With the absence of any vaccine targeting any parasitic protozoa and resistance against the already existing anti-parasitic drugs, research efforts have been employed and encouraged towards the search for new, cheaper, potent and effective drugs to treat these diseases. Medicinal plants represent a potential source of new drugs. This is because natural products (NPs) from organisms such as animals, fungi and the higher plants have been known to be good sources of pharmacologically active compounds against several ailments, including protozoal infections. Moreover, NPs are believed to have significant advantages as lead molecules over synthetic molecules. ${ }^{39-48}$ The criteria for choosing a particular natural product for studies are either based on the pre-existing traditional use of the source species in therapy (ethnobotanical knowledge) or the search for structurally related molecules with known pharmacologically active agents from chemical databases. ${ }^{49-54}$ The African continent is highly diverse ethnobotanically. This might explain why about $80 \%$ of the population tends to rely on medicinal plants as a primary source of healthcare. ${ }^{55-67}$ It is our goal to provide evidence of the efficacy and potency of plants used in traditional medicine against protozoal infections. The systematic documentation of the plant-based chemical constituents of African traditional medicine and attempting to using in silico procedures to investigate their modes of action are ongoing efforts, ${ }^{44-46,52,53}$ particularly on the isolated compounds from African medicinal plants (AMPs) with evaluated in vitro and/or in vivo activities against trypanosomiasis, ${ }^{68-74}$ schistosomiasis, leishmaniasis $^{73,74}$ and other parasitic protozoal diseases. ${ }^{4}$ However, the most recent review dates about 3 years back and was focused only on plants collected from Nigeria. Thus, an updated review that covers the entire continent for these three protozoal parasitic diseases is required now. The information presented herein was retrieved by searching literature from major international journals on natural products and medicinal chemistry, alongside available M.Sc. and Ph.D. theses and online databases. ${ }^{54,75}$ The information gathered is discussed under the main compound classes, as presented below and summarised in Table 1.

\section{Alkaloids}

This class is characterized by nitrogen-containing compounds that are naturally occurring. Diverse species (fungi, plants, animals) have yielded several bioactive alkaloids against a broad range of diseases. ${ }^{76-84}$ Table 1 summarises the alkaloids (compounds 1 - 33) isolated from AMPs and evaluated against these parasitic diseases, while Figures 2 to 5 show a selection of some promising alkaloidal compounds, based on their evaluated activity $(<12.41 \mu \mathrm{M})$.

\subsection{Naphthylisoquinolines}

The leaves, stem bark and roots of Ancistrocladus sp. (Ancistrocladaceae) are known to be rich sources of naphthylisoquinoline alkaloids (Figure 2). ${ }^{85-91}$ Ancistrocladidine

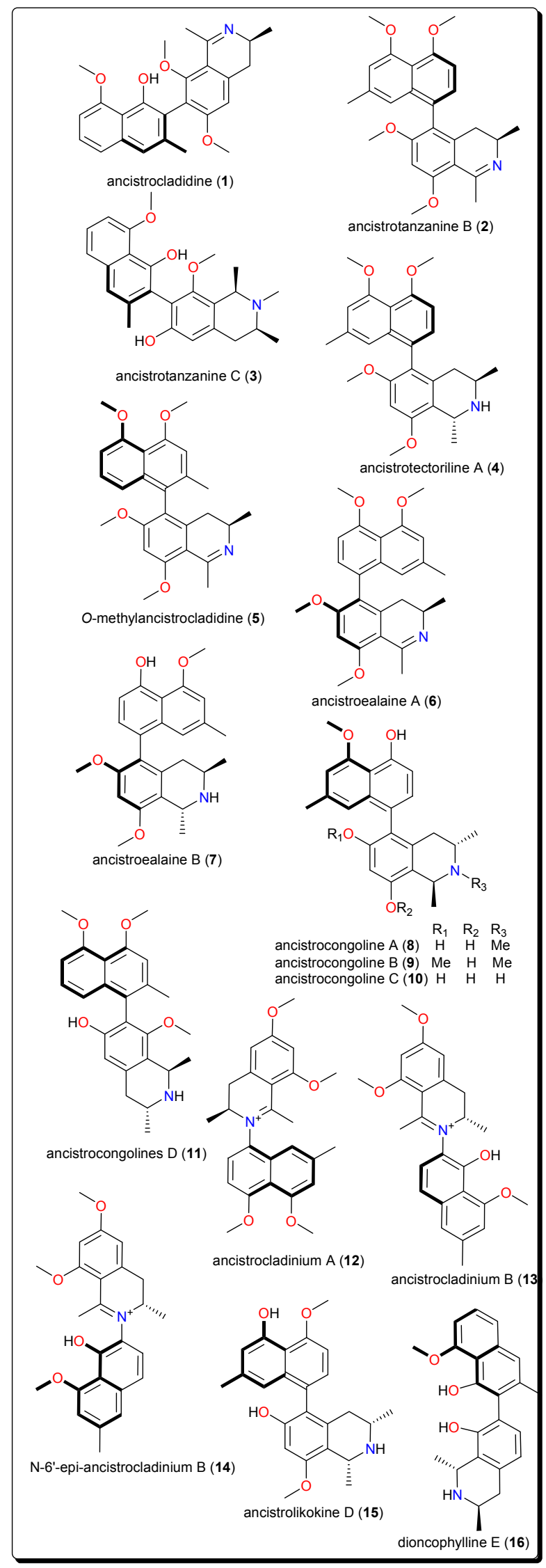

Fig. 2. Antiprotozoal naphthylisoquinoline alkaloids. 
Table 1: Bioactive alkaloids from African flora with potential for antitrypanosomal and antileischmanial drug discovery.

\begin{tabular}{|c|c|c|c|c|c|c|c|c|}
\hline $\begin{array}{c}\text { Compound } \\
\text { number }\end{array}$ & $\begin{array}{l}\text { Compound class / } \\
\text { Subclass }\end{array}$ & $\begin{array}{l}\text { Part of plant } \\
\text { studied }\end{array}$ & Species name & Plant family & Place of collection & Used traditionally/locally & $\begin{array}{l}\text { Reported activity } \\
\text { on/against }\end{array}$ & Ref. \\
\hline $1-5$ & \multirow{6}{*}{$\begin{array}{l}\text { Alkaloid / } \\
\text { Naphthylisoquinoline }\end{array}$} & Leaves & $\begin{array}{l}\text { Ancistrocladus } \\
\text { tanzaniensis }\end{array}$ & $\begin{array}{l}\text { Asteraceae } \\
\text { (Compositae) }\end{array}$ & $\begin{array}{l}\text { Uzungwa Mountains, } \\
\text { Tanzania }\end{array}$ & \multirow{5}{*}{$\begin{array}{l}\text { different species of Ancistrocladus are } \\
\text { used as a diuretic; also for the treatment } \\
\text { of malaria, dysentery, elephantiasis, } \\
\text { febrile and phlogistic. }\end{array}$} & $\begin{array}{l}\text { Trypanosomiasis } \\
\text { and } \\
\text { leishmanosomiasis }\end{array}$ & 85,86 \\
\hline 6,7 & & $\begin{array}{l}\text { Leaves, stem } \\
\text { bark and roots }\end{array}$ & $\begin{array}{l}\text { Ancistrocladus } \\
\text { ealaensis }\end{array}$ & $\begin{array}{l}\text { Asteraceae } \\
\text { (Compositae) }\end{array}$ & $\begin{array}{l}\text { Eala, Democratic } \\
\text { Republic of Congo }\end{array}$ & & $\begin{array}{l}\text { Trypanosomiasis } \\
\text { and } \\
\text { leishmanosomiasis }\end{array}$ & 87 \\
\hline $8-11$ & & $\begin{array}{l}\text { Stem and root } \\
\text { bark }\end{array}$ & $\begin{array}{l}\text { Ancistrocladus } \\
\text { congolensis }\end{array}$ & $\begin{array}{l}\text { Asteraceae } \\
\text { (Compositae) }\end{array}$ & $\begin{array}{l}\text { Yandja-Rive, } \\
\text { Democratic Republic } \\
\text { of Congo }\end{array}$ & & Trypanosomiasis & 88 \\
\hline $12-14$ & & Leaves & $\begin{array}{l}\text { Ancistrocladus } \\
\text { species }\end{array}$ & $\begin{array}{l}\text { Asteraceae } \\
\text { (Compositae) }\end{array}$ & $\begin{array}{l}\text { Ikela, Democratic } \\
\text { Republic of Congo }\end{array}$ & & $\begin{array}{l}\text { Trypanosomiasis } \\
\text { and } \\
\text { leishmanosomiasis }\end{array}$ & 89 \\
\hline 15 & & Roots & $\begin{array}{l}\text { Ancistrocladus } \\
\text { likoko }\end{array}$ & $\begin{array}{l}\text { Asteraceae } \\
\text { (Compositae) }\end{array}$ & $\begin{array}{l}\text { Yangambi, } \\
\text { Democratic Republic } \\
\text { of Congo }\end{array}$ & & $\begin{array}{l}\text { Trypanosomiasis } \\
\text { and } \\
\text { leishmanosomiasis }\end{array}$ & 90 \\
\hline 16 & & Roots & $\begin{array}{l}\text { Dioncophyllum } \\
\text { thollonii }\end{array}$ & Dioncophyllaceae & Rabi Kounga, Gabon & $\begin{array}{l}\text { for treatment of malaria, leishmaniasis, } \\
\text { dysentery and elephantiasis }\end{array}$ & $\begin{array}{l}\text { Trypanosomiasis } \\
\text { and } \\
\text { leishmanosomiasis }\end{array}$ & 91 \\
\hline 17,18 & Alkaloid /Aporphine & Aerial parts & $\begin{array}{l}\text { Cassytha } \\
\text { filiformis }\end{array}$ & Lauraceae & Sèmè, Ouémé, Benin & $\begin{array}{l}\text { to treat cancer, African trypanosomiasis } \\
\text { and other diseases }\end{array}$ & Trypanosomiasis & 95 \\
\hline $19-28$ & Alkaloid / Quinoline & Roots & Waltheria indica & Malvaceae & Inder, Niger & $\begin{array}{l}\text { to treat cough, fever, external } \\
\text { haemorrhage, dysentery, toothache, } \\
\text { malaria, eye drop }\end{array}$ & Trypanosomiasis & 98 \\
\hline $29-33$ & $\begin{array}{l}\text { Alkaloid / Indoles } \\
\text { and others }\end{array}$ & Stem bark & $\begin{array}{l}\text { Polyalthia } \\
\text { suaveolens }\end{array}$ & Annonaceae & Yaoundé, Cameroon & to treat rheumatic pains & Trypanosomiasis & 106 \\
\hline
\end{tabular}


(1), ancistrotanzanines B (2), and C (3), ancistrotectoriline A (4), $O$-methylancistrocladidine (5), ancistroealaines A (6) and B (7), ancistrocongolines A-D (8-11), ancistrocladiniums A (12) and B (13), N-6'-epi-ancistrocladinium B (14), ancistrolikokine D (15) and dioncophylline E (16) are few examples of naphthylisoquinoline antiprotozoal alkaloids from Ancistrocladus sp. and Dioncophyllum thollonii (Dioncophyllaceae).

The evaluation of the biological activities of these compounds showed them to be a rare set and promising class of antiprotozoal and antiviral agents, which are only found in plants of the Ancistrocladaceae and Dioncophyllaceae, mostly found in Africa. Their anti-Trypanosoma activities are evident (e.g. with $\mathrm{IC}_{50}$ values ranging from 0.17 to $12.41 \mu \mathrm{M}$ against Trypanosoma brucei rhodesiense), alongside good to moderate activities against Trypanosoma cruzi and Leishmania donovani. It might be worth mentioning that the isoquinoline scaffold has also been explored synthetically for the discovery of novel antiprotozoals and antimicrobials. . $^{8,86,92-94}$

\subsection{Aporphines}

Other bioactive alkaloids include the aporphines (Figure 3); actinodaphnine (17) and cassythine (18) from Cassytha filiformis (Lauraceae), a plant whose alkaloidal extract showed activity against $T$. b. brucei (with an $\mathrm{IC}_{50}$ value of $2.2 \mu \mathrm{g} / \mathrm{mL}$ ). This confirmed the use of this plant in African folkloric medicine to treat African trypanosomiasis and other diseases. ${ }^{95-97}$ The isolated compounds displayed antitrypanosomal activities, with $\mathrm{IC}_{50}$ values of 10.29 and $17.60 \mu \mathrm{M}$ for compounds $\mathbf{1 7}$ and $\mathbf{1 8}$, respectively. Although, the compounds showed low selectivity indices to $\mathrm{HeLa}$ cells (e.g. for actinodaphnine, $\mathrm{IC}_{50}(\mathrm{HeLa}) / \mathrm{IC}_{50}$ $(T$. b. brucei $)<5)$, when compared with the alkaloidal fraction (selectivity index $=16$ ), they represent good starting scaffolds that could be optimised in order to improve the efficacy and selectivity in the search for new bioactive molecules with trypanocidal effects.

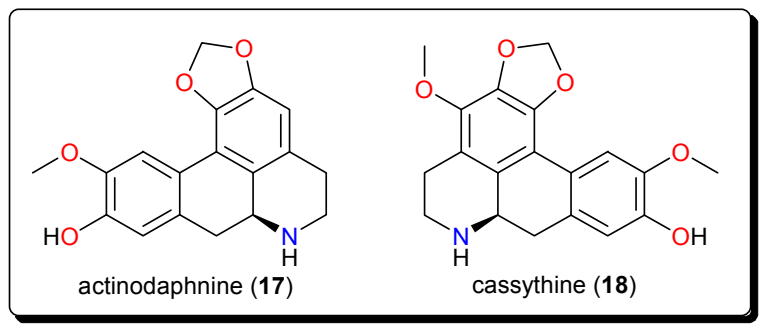

Fig. 3. Aporphine alkaloids with trypanosidal potencies.

\subsection{Quinolines}

Other trypanocidal alkaloids include the quinolines (Figure 4); waltheriones E-L (19-26), 8-deoxoantidesmone (27) and antidesmone (28) from Waltheria indica (Malvaceae). ${ }^{98}$ This plant is used in traditional medicine for the treatment of several ailments, including malaria. ${ }^{99-103}$ The dichloromethane root extract showed activities against $T$. cruzi $\left(\mathrm{IC}_{50}=0.74 \mu \mathrm{g} / \mathrm{mL}\right), T$. b. brucei $\left(2.3 \%\right.$ survival at $20 \mu \mathrm{g} / \mathrm{mL}$ ) and $T$. b. rhodesiense ( $\mathrm{IC}_{50}$ $=17.4 \mu \mathrm{g} / \mathrm{mL}) .{ }^{98}$ With the exception of waltherione $\mathrm{L}(\mathbf{2 6})$, with a slightly higher $\operatorname{IC}_{50}(3.1 \mu \mathrm{M})$, the isolated compounds all displayed potent growth inhibition toward the amastigote form of T. cruzi (the Tulahuen $\mathrm{C} 4$ strain), with $\mathrm{IC}_{50}$ values lower than that of the reference drug benznidazole $\left(\mathrm{IC}_{50}=2.9 \mu \mathrm{M}\right)$. Structureactivity relationships (SARs) provide suggestions that, a methoxy group, bound to the nitrogen atom is important for activity (e.g. as in compounds 22, 24 and 25). This group at this position increased the lethality of $T$. cruzi. Furthermore, the absolute configuration $(5 R)$ (as in compounds $23,26,27$ ) seems to result in a decrease of activity, while the presence of an N-oxide function (as in compound 26) is detrimental for T. cruzi inhibitory activity (Figure 5). Finally, a comparison of the $\mathrm{IC}_{50}$ values of the isolated compounds against $T$. brucei $\mathrm{sp}$. and $T$. cruzi highlighted selective toxicity towards the latter. This suggests that these molecules (or the waltherione scaffold) is a potential starting point for new safe antitrypanocidal drug development, although antidesmone (28) has already been patented for its potential as an antiprotozoal drug since $2003 .{ }^{98,104,105}$

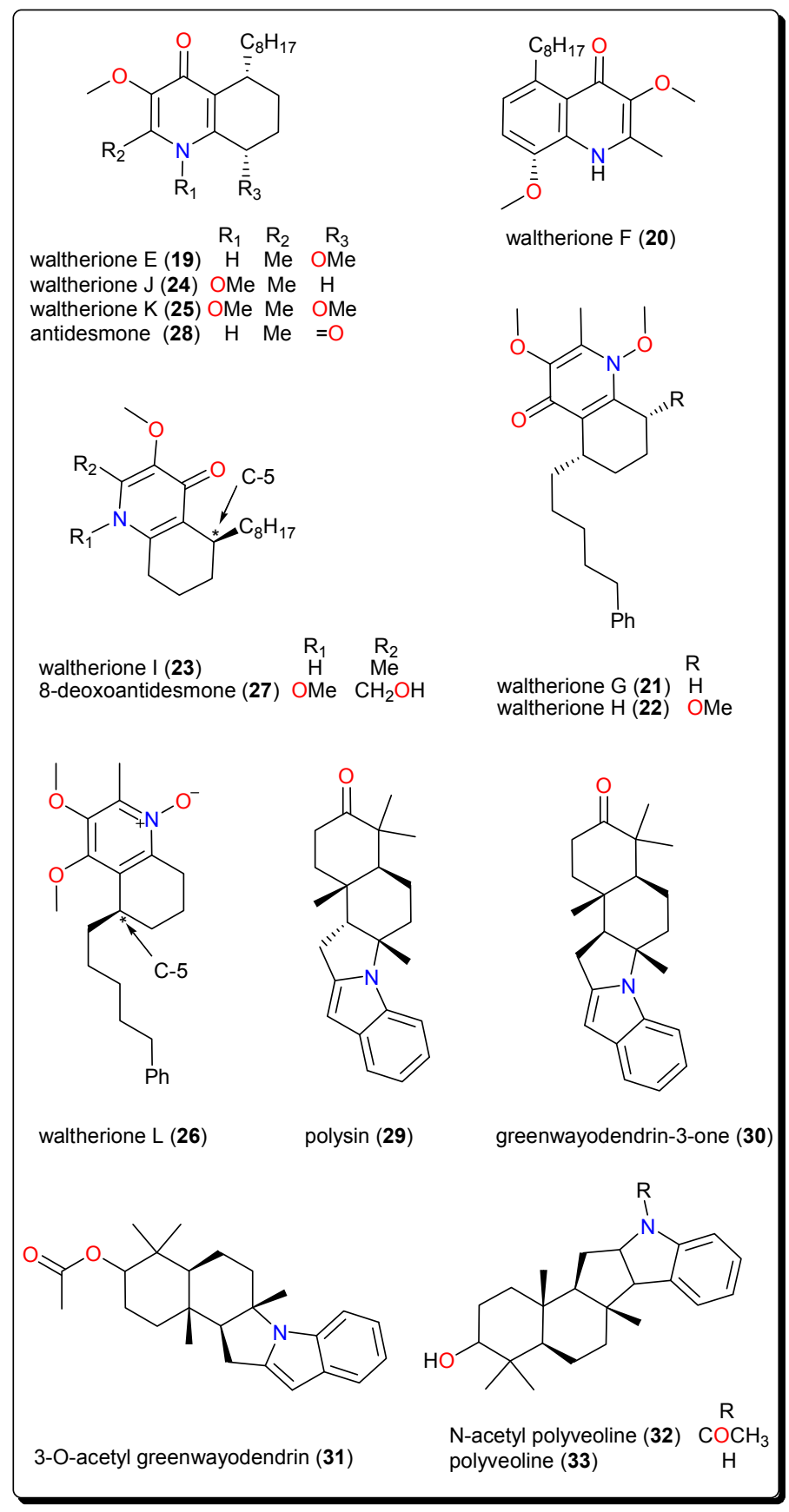

Fig. 4. Quinoline, indoles and other alkaloids showing activities against Trypanosoma species.

\subsection{Indoles and other alkaloids}

Polysin (29), an indolosesquiterpene alkaloid from Polyalthia suaveolens (Annonaceae), was isolated together with the known alkaloids (Figure 4); greenwayodendrin-3-one (30), 3-O-acetyl 
greenwayodendrin (31), N-acetyl polyveoline (32) and polyveoline (33). These alkaloids have demonstrated interesting activities on selected glycolytic enzymes, e.g. phosphofructo kinase (PFK), glyceraldehyde-3-phosphate dehydrogenase (GAPDH) and aldolase. ${ }^{106}$ Of particular interest are polysin (29) and 3-O-acetyl greenwayodendrin (31). Compound 29 acted as a competitive reversible inhibitor against $T$. brucei $\mathrm{PFK}\left(\mathrm{K}_{\mathrm{i}}=10\right.$ $\mu \mathrm{M}$ ), while compound $\mathbf{3 1}$ acted as a selective inhibitor of $T$. brucei aldolase (with $\mathrm{IC}_{50} \sim 0.5 \mu \mathrm{M}$ ). Meanwhile, polyveoline (33) acted as a selective inhibitor of T. brucei PFK and is a mixed reversible inhibitor of $T$. brucei GAPDH. These compounds, therefore, represent a good starting point for the design of new selective and potent trypanosomal drugs.

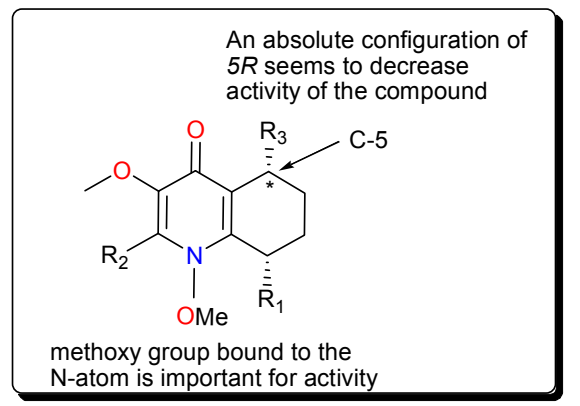

Fig. 5. SAR for W. indica compounds inhibiting T. cruzi, T. $b$. brucei and T. b. rhodesiense.

\section{Terpenoids}

Terpenoids constitute a large and diverse class of naturally occurring secondary metabolites, with interesting physiological and pharmacological functions. ${ }^{45,107-110}$ Their main scaffolds occur as multicyclic structures, e.g. hemi-terpenoids (5 carbon atoms), monoterpenoids (10 carbon atoms), sesquiterpenoids (15 carbon atoms), diterpenoids (20 carbon atoms), sesterterpenoids (25 carbon atoms), triterpenoids (30 carbon atoms), tetraterpenoids (40 carbon atoms), and polyterpenoids (more than 40 carbon atoms), which are all primarily derived from the fivecarbon isoprene units. ${ }^{45,107}$ Terpenoids have been proven to possess interesting pharmacological activities as seen in the summary presented in Table 2 (compounds 34 - 61) and their corresponding structures shown in Figures 6 to $10 .^{45,105,111-114}$

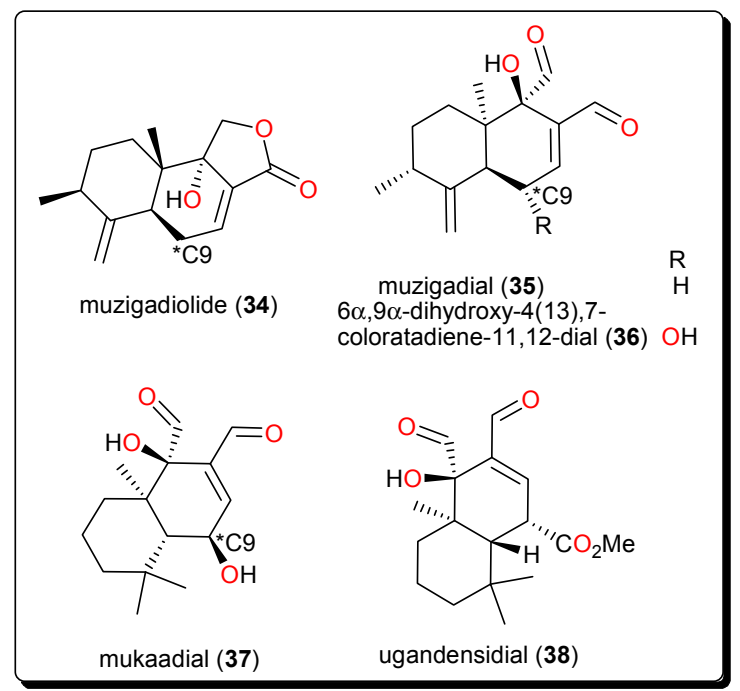

Fig. 6. Sesquiterpenoids which have demonstrated antiTrypanosoma activities

\subsection{Sesquiterpenoids}

The sesquiterpenoids (Figure 6), muzigadiolide (34), muzigadial (35), $6 \alpha, 9 \alpha$-dihydroxy-4(13),7-coloratadiene-11,12dial (36), mukaadial (37) and ugandensidial (38), from the East African medicinal plant Warburgia ugandensis (Canellaceae) have demonstrated anti-Trypanosoma activities. ${ }^{15}$ The compounds displayed in vitro activities (with $\mathrm{IC}_{50}$ values ranging from 0.64 to $6.4 \mu \mathrm{M}$ ) against $T$. $b$. rhodesiense, the parasite responsible for African sleeping sickness. Compound 37 had previously been isolated from the same plant, also showing antitrypanocidal activity. ${ }^{116}$ This plant (now regarded as an endangered species) has attracted many researchers because of its traditional use for the treatment of a variety of ailments, including malaria and diverse fevers. ${ }^{115-117}$ SAR studies suggested that an additional dialdehyde functional group to the sesquiterpene lactone backbone, together with a hydroxyl group attached to C-9 contribute to the activity of the compounds.

\subsection{Carvotacetone derivatives}

The native tropical East African medicinal plant Sphaeranthus bullatus (synonym: S. gallensis Sacleux, Family: Asteraceae) has been the origin of several compounds (Figure 7), ${ }^{118-120}$ including the carvotacetone derivatives; 3-acetoxy-7-hydroxy-5tigloyloxycarvotacetone (39), 3,7-dihydroxy-5tigloyloxycarvotacetone (40) and 3-acetoxy-5,7dihydroxycarvotacetone (41). Compounds 39-41 demonstrated antileishmanial activities, with $\mathrm{IC}_{50}$ values of $2.16,10.64$ and $2.89 \mu \mathrm{M}$, respectively, against the parasite $L$. donovanii promastigotes.

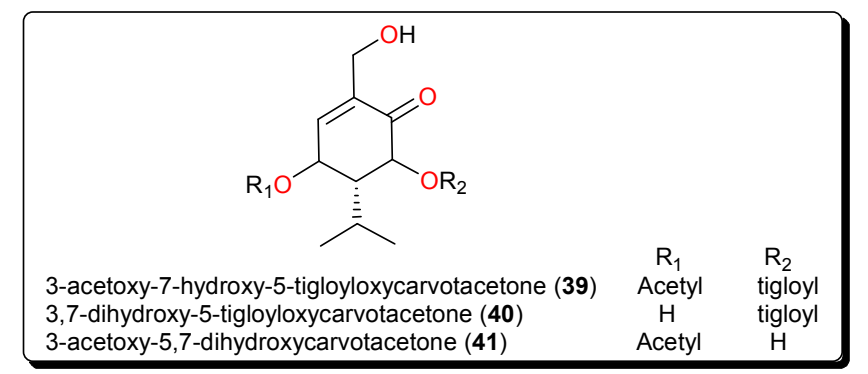

Fig. 7. Carvotacetones with potent antileishmanial activities

\subsection{Diterpenoids}

Other terpenoids include the abietane diterpenoids, taxodione (42) and uncinatone (43), Fig. 8, from the roots of Clerodendrum eriophyllum (Verbenaceae), ${ }^{121}$ which displayed potent antileishmanial activities (with $\mathrm{IC}_{50}$ values of 0.25 and $0.61 \mu \mathrm{M}$, respectively) against $L$. donovanii. The activities of the crude extracts, e.g. the hexane extract of Polyalthia longifolia (Annonaceae) $\left(\mathrm{EC}_{50} 2.4 \mu \mathrm{g} / \mathrm{mL}\right)$, the ethyl acetate extracts of Newbouldia laevis (Bignoniaceae) (EC50 $4.2 \mu \mathrm{g} / \mathrm{mL}$ ) and Eucalyptus maculata (Myrtaceae) (EC $\mathrm{EC}_{50} 12.3 \mu \mathrm{g} / \mathrm{mL}$ ) and their isolated active compounds (Figure 8); 16- $\alpha$-hydroxy-cleroda-3-13(-14)z-dien15,16-olide (44), kolavenic acid (45), polyalthiadioic acid (46) and the triterpenoid $3 \beta, 13 \beta$-dihydroxy-urs-11-en-28-oic acid (47) were observed against different trypanosomes strains (s427 WT, B48 and AQP2/3KO). ${ }^{122}$ While these pure compounds exhibited activities against the tested strains, with $\mathrm{EC}_{50}$ values ranging from 1.16 to $40.46 \mu \mathrm{M}$, it was remarkable that no toxicity towards Human Embryonic Kidney cells was observed even at concentrations up to $400 \mu \mathrm{g} / \mathrm{mL}(1,315.78 \mu \mathrm{M})$, thus suggesting new scaffolds to be further developed for the treatment of the wild-type and multi-drug resistant $T$. brucei $^{122,123}$ Also interesting is the kolavic acid derivative; monomethyl ester-15kolavic acid (48) isolated from Entada abyssinica (Fabaceae), ${ }^{124}$ 
Table 2: Bioactive terpenoids from African flora with potential for antitrypanosomal anti-

Schistosoma and antileischmanial drug discovery.

\begin{tabular}{|c|c|c|c|c|c|c|c|c|}
\hline $\begin{array}{l}\text { Compound } \\
\text { number }\end{array}$ & $\begin{array}{l}\text { Compound class / } \\
\text { Subclass }\end{array}$ & $\begin{array}{l}\text { Part of plant } \\
\text { studied }\end{array}$ & Species name & Plant family & Place of collection & Used traditionally/locally & $\begin{array}{l}\text { Reported activity } \\
\text { on/against }\end{array}$ & Ref. \\
\hline $34-38$ & $\begin{array}{l}\text { Terpenoid / } \\
\text { Sesquiterpenoids }\end{array}$ & Stem bark & $\begin{array}{l}\text { Warburgia } \\
\text { ugandensis }\end{array}$ & Canellaceae & $\begin{array}{l}\text { Harena Forest, Dello } \\
\text { Menna, Ethiopia }\end{array}$ & $\begin{array}{l}\text { treatment of various ailments such as } \\
\text { common cold, fever, malaria, } \\
\text { stomachache, constipation snakebites } \\
\text { measles and diarrheal, This plant is also } \\
\text { a common component in a number of } \\
\text { medicinal preparations. }\end{array}$ & Trypanosomiasis & 115 \\
\hline $39-41$ & $\begin{array}{l}\text { Terpenoid / } \\
\text { Carvotacetone } \\
\text { derivatives }\end{array}$ & Aerial parts & $\begin{array}{l}\text { Sphaeranthus } \\
\text { bullatus } \\
\text { (synonym: } S . \\
\text { gallensis Sacleux) }\end{array}$ & Asteraceae & $\begin{array}{l}\text { Ngong forest, Nairobi, } \\
\text { Kenya }\end{array}$ & $\begin{array}{l}\text { usually consumed as herbal tea for the } \\
\text { management of diarrhea. }\end{array}$ & Leishmanosomiasis & 118 \\
\hline 42,43 & Terpenoid & Roots & $\begin{array}{l}\text { Clerodendrum } \\
\text { eriophyllum }\end{array}$ & Verbenaceae & $\begin{array}{l}\text { Machakos, Eastern } \\
\text { Kenya }\end{array}$ & treatment of malaria & Leishmanosomiasis & 121 \\
\hline $44-46$ & \multirow{2}{*}{$\begin{array}{l}\text { Terpenoid / } \\
\text { Diterpenoid }\end{array}$} & Leaves & $\begin{array}{l}\text { Polyalthia } \\
\text { longifolia }\end{array}$ & Annonaceae & $\begin{array}{l}\text { Anyigba, Kogi State, } \\
\text { Nigeria }\end{array}$ & $\begin{array}{l}\text { to treat various protozoan infections } \\
\text { including species of Trypanosoma, } \\
\text { Leishmania, and Plasmodium }\end{array}$ & Trypanosomiasis & 122 \\
\hline 47 & & Leaves & $\begin{array}{l}\text { Eucalyptus } \\
\text { maculata }\end{array}$ & Myrtaceae & $\begin{array}{l}\text { Anyigba, Kogi State, } \\
\text { Nigeria }\end{array}$ & $\begin{array}{l}\text { to treat various protozoan infections } \\
\text { including species of Trypanosoma, } \\
\text { Leishmania, and Plasmodium }\end{array}$ & Trypanosomiasis & 122 \\
\hline 48 & $\begin{array}{l}\text { Terpenoid / } \\
\text { Diterpenoid }\end{array}$ & Bark & Entada abyssinica & Fabaceae & Dschang, Cameroon & to treat sleeping sickness & Trypanosomiasis & 124 \\
\hline $49-51$ & $\begin{array}{l}\text { Terpenoid / } \\
\text { Diterpenoid }\end{array}$ & Fruits & $\begin{array}{l}\text { Xylopia } \\
\text { aethiopica }\end{array}$ & Annonaceae & $\begin{array}{l}\text { Nkongsamba, } \\
\text { Cameroon }\end{array}$ & $\begin{array}{l}\text { to treat bronchitis and dysenteric among } \\
\text { other ailments. }\end{array}$ & Trypanosomiasis & 126 \\
\hline 52 & $\begin{array}{l}\text { Terpenoid / } \\
\text { Diterpenoid }\end{array}$ & Rhizomes & $\begin{array}{l}\text { Aframomum } \\
\text { sceptrum }\end{array}$ & Zingiberaceae & Ivory Coast & $\begin{array}{l}\text { in addition to their spiritual belief from } \\
\text { the plant species, they are as well used } \\
\text { as food spice, and for the treatment of } \\
\text { inflammation, eczema, fevers, laxative, } \\
\text { anti-helmintic, mumps, etc. }\end{array}$ & $\begin{array}{l}\text { Trypanosomiasis } \\
\text { and } \\
\text { leishmanosomiasis }\end{array}$ & 128 \\
\hline 53 & $\begin{array}{r}\text { Terpenoid / } \\
\text { Triterpenoid }\end{array}$ & Roots & $\begin{array}{l}\text { Asparagus } \\
\text { stipularis }\end{array}$ & Asparagaceae & Sinai, Egypt & $\begin{array}{l}\text { to treat Schistosomiasis (bilharziasis) } \\
\text { amongst other ailments }\end{array}$ & Schistosomiasis & 131 \\
\hline 54 & \multirow[t]{2}{*}{$\begin{array}{l}\text { Terpenoid / } \\
\text { Diterpenoid }\end{array}$} & Root barks & $\begin{array}{l}\text { Elaeodendron } \\
\text { schlechteranum }\end{array}$ & Celastraceae & $\begin{array}{l}\text { Bunda district, } \\
\text { Kung'ombe, Tanzania }\end{array}$ & $\begin{array}{l}\text { treatment of anaemia, general body } \\
\text { pain, dysmenorrhea, female infertility } \\
\text { and male impotence, boils, carbuncles, } \\
\text { cardiovascular problems including } \\
\text { hypertension and joint inflammation. }\end{array}$ & $\begin{array}{l}\text { Trypanosomiasis } \\
\text { and } \\
\text { leishmanosomiasis }\end{array}$ & 133 \\
\hline 55,56 & & Roots & $\begin{array}{l}\text { Salacia } \\
\text { madagascariensis }\end{array}$ & Celastraceae & Tanzania & treat malaria, fever, and menorrhagia & Leishmanosomiasis & 135 \\
\hline 57,58 & $\begin{array}{l}\text { Terpenoid / } \\
\text { Diterpenoid and } \\
\text { Triterpenoid }\end{array}$ & Leaves & $\begin{array}{l}\text { Keetia leucantha } \\
\text { (synonym: } \\
\text { Plectronia } \\
\text { leucantha Krause) }\end{array}$ & Rubiaceae & Benin & to treat parasitic diseases & Trypanosomiasis & 138 \\
\hline 59 & $\begin{array}{l}\text { Terpenoid / } \\
\text { Diterpenoid }\end{array}$ & Stem bark & $\begin{array}{l}\text { Piptostigma } \\
\text { preussi }\end{array}$ & Annonaceae & Ebolowa, Cameroon & To treat malaria & $\begin{array}{l}\text { Trypanosomiasis } \\
\text { activity }\end{array}$ & 139 \\
\hline 60,61 & $\begin{array}{l}\text { Terpenoid / } \\
\text { Triterpenoid }\end{array}$ & Stem bark & $\begin{array}{l}\text { Vernonia } \\
\text { guineensis }\end{array}$ & $\begin{array}{l}\text { Asteraceae } \\
\text { (Compositae) }\end{array}$ & Bafoussam, Cameroon & $\begin{array}{l}\text { to treat malaria and jaundice as well as } \\
\text { an anthelmintic, an aphrodisiac and an } \\
\text { anti-dote to poison }\end{array}$ & Trypanosomiasis & 142 \\
\hline
\end{tabular}


which demonstrated interesting selective inhibitory activity $\left(\mathrm{IC}_{50}\right.$ value of $0.012 \mathrm{mM}$ ) against $T$. brucei GAPDH. ${ }^{125}$

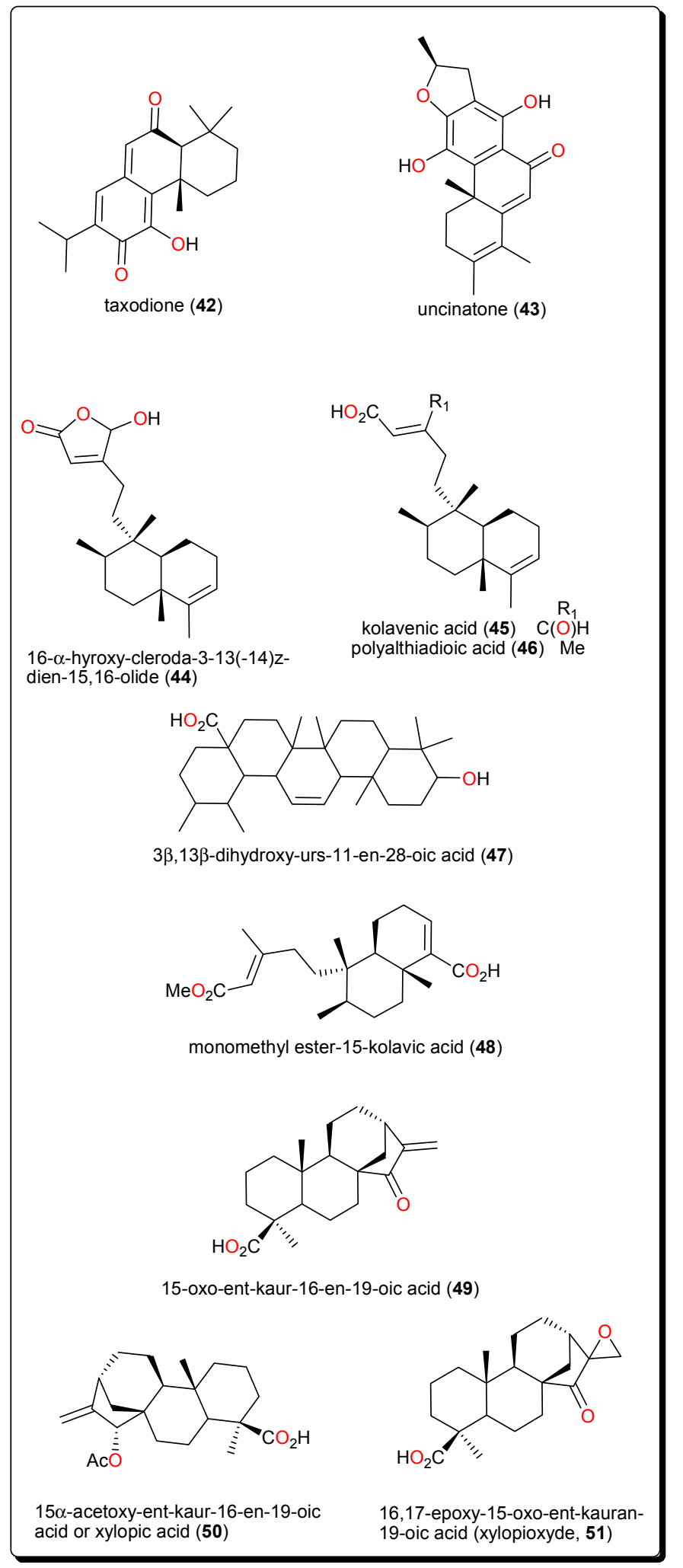

Fig. 8. Diterpenoids and a triterpenoid with selective inhibitory activity against $T$. brucei GAPDH.

Other bioactive diterpenoids include 15-oxo-ent-kaur-16-en-19oic acid (49), 15 $\alpha$-acetoxy-ent-kaur-16-en-19-oic acid or xylopic acid, (50) and 16,17-epoxy-15-oxo-ent-kauran-19-oic acid or xylopioxyde (51), from fruits of Xylopia aethiopica (Annonaceae). ${ }^{126}$ These compounds and their synthetic epoxide analogues were screened on antitrypanosomal and cytotoxicity assays, showing that only the naturally-occurring compounds (49-51) displayed cytotoxic effects on the mammalian fibroblast cell line MRC-5 (with $\mathrm{ED}_{50}$ values ranging from 22 to $121 \mu \mathrm{M}$ ), as well as inhibitory effects on the growth of the bloodstream forms of T. b. brucei cells (strain 241) (ED $\mathrm{ED}_{50}$ ranging from 27 to $205 \mu \mathrm{M})$.

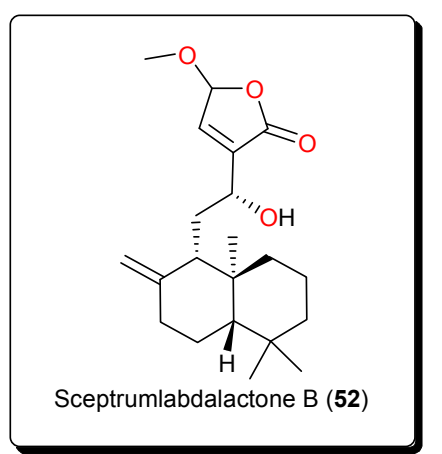

Fig. 9. Potent compound with selective activity for $L$. donovani, when compared with the activity against $T$. b. brucei.

The genus Aframomum (Zingiberaceae), has been the source of the antitryposonomals. Sceptrumlabdalactone B (52, Figure 9) was identified, from the rhizomes of $A$. sceptrum, a plant locally used for the treatment of infectious diseases including human African trypanosomiasis (sleeping sickness), together with sceptrumlabdalactone A. ${ }^{127-130}$ The activity of compound $\mathbf{5 2}$ (with $\mathrm{IC}_{50}$ value of $5.7 \mu \mathrm{M}$ ) against $L$. donovani was comparable to that of reference drugs ( $\mathrm{IC}_{50}$ of 2.5 and $3.0 \mu \mathrm{M}$ for pentamidine and miltefosine respectively). Additionally, this molecule demonstrated selective activity for $L$. donovani, when compared with the activity against $T$. b. brucei.

\subsection{Triterpenoids}

Asparagalin A (53, Figure 10), from the Egyptian medicinal plant Asparagus stipularis (Asparagaceae), ${ }^{131}$ was able to significantly reduce the ability of adult female worms to lay eggs. It was further shown that the compound had some suppressive effect on egg-laying capacity in a dose-dependence manner. ${ }^{132}$ Elaeodendron schlechteranum (Celastraceae) is the source of tingenin B or $22 \beta$-hydroxytingenone (54). ${ }^{133}$ This compound has displayed a broad range of activities e.g. against T. cruzi $\left(\mathrm{IC}_{50}<\right.$ $0.57 \mu \mathrm{M})$, T. brucei $(<0.57 \mu \mathrm{M})$, L. infantum $(1.67 \mu \mathrm{M})$, and $P$. falciparum $(0.83 \mu \mathrm{M})$, confirming the claim of the applicability of the plant in traditional medicine to treat various non-infectious diseases. ${ }^{63,134}$ Albeit, being highly cytotoxic to MRC-5 cells $\left(\mathrm{CC}_{50} 0.45 \mu \mathrm{g} / \mathrm{mL}\right)$, indicates a poor selectivity to normal cells. Further studies on this compound could be considered in order to suggest less toxic and more selective analogues for the development of novel antiparasitics. The bisnortriterpenes from Salacia madagascariensis (Celastraceae); isoiguesterin (55) and 20-epi-isoiguesterinol (56) showed potent activities against Leishmania sp. ${ }^{135}$ Meanwhile, isoiguesterin (55) and 20-epiisoiguesterinol (56) displayed comparable activities with chloroquine and artemisinin against the D6 clone, being more potent and selective against L. donovani (a species known to cause visceral leishmaniasis). When compared with amphotericin $\mathrm{B}$, used currently in the treatment of leishmaniasis, compounds 55 and 56 show great potential for future selective drug development against Leishmania. 


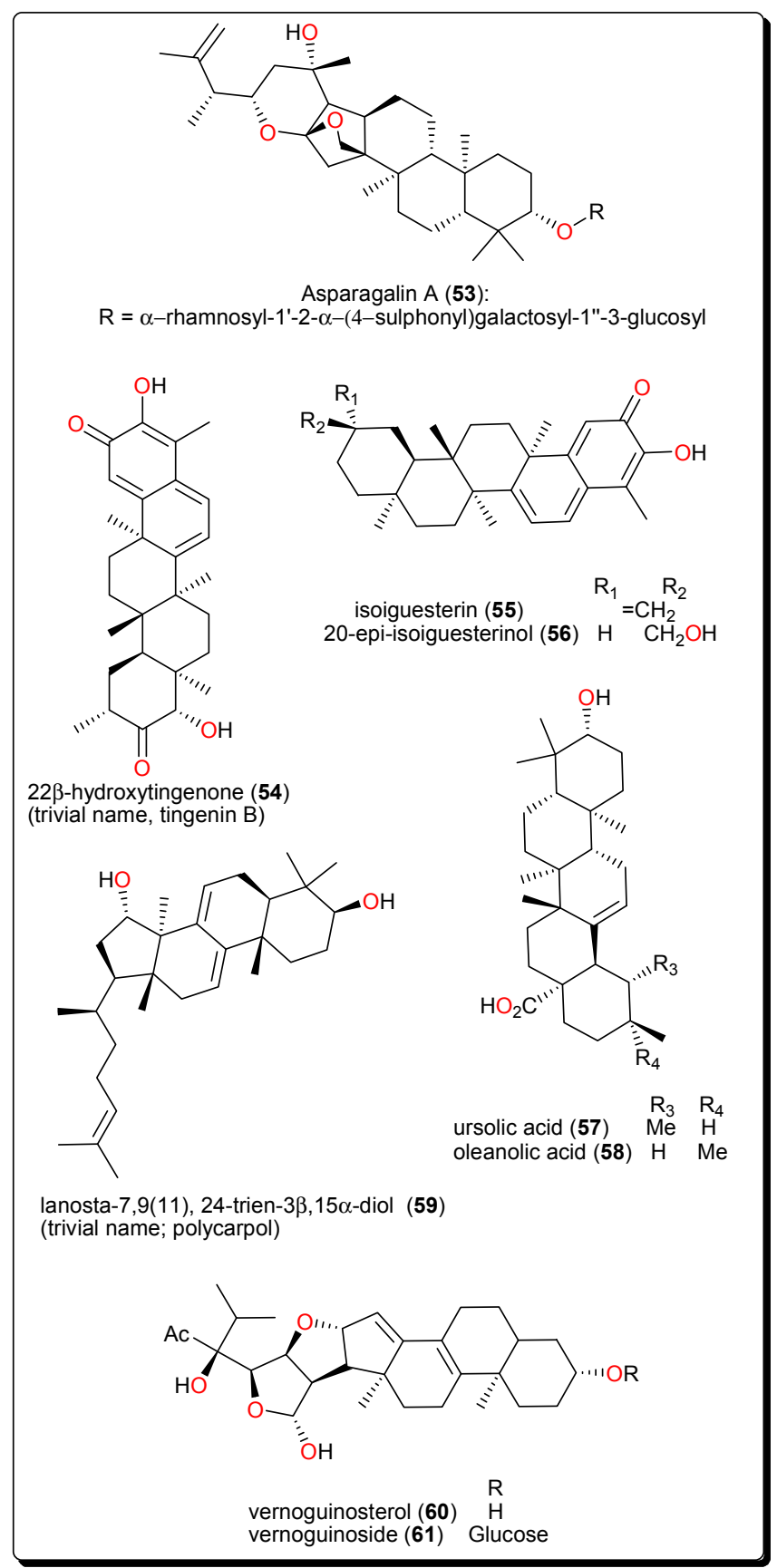

Fig. 10. Triterpenoids with antiprotozoal activities.

Keetia leucantha (synonym: Plectronia leucantha Krause) is a West African tree of the Rubiaceae, used to treat a variety of infections, including parasitic infections. ${ }^{136,137}$ Ursolic acid (57) and oleanolic acid (58), along with other constituents were isolated from the leaves of this plant. An investigation of the antitrypanosomal activities of essential oil, the dichloromethane extract and isolated compounds on $T$. b. brucei bloodstream forms (Tbb BSF) and procyclic forms (Tbb PF) ${ }^{138}$ showed that ursolic acid (57) and oleanolic acid (58) were the most bioactive tested compounds. ${ }^{138}$ Ursolic acid displayed $\mathrm{IC}_{50}$ values of 5.48 and $14.25 \mu \mathrm{M}$, respectively, on Tbb BSF and Tbb PF, while oleanolic acid displayed an $\mathrm{IC}_{50}$ value of $16.00 \mu \mathrm{M}$ on Tbb BSF. This could explain why the plant is effective in the traditional treatment of parasitic-related ailments. Another identified triterpenoid was polycarpol or lanosta-7,9(11),24-trien-3 $\beta, 15 \alpha$ diol (59) from Piptostigma preussi (Annonaceae). ${ }^{139}$ The compound showed antitrypanosomal activity with an $\mathrm{ED}_{50}$ value of $5.11 \mu \mathrm{M}$ on $T$. brucei cells. An investigation of its mode of action showed that the compound acted by inhibiting $T$. brucei glycolytic enzymes GAPDH and PFK (glycolytic pathway enzymes validated by WHO as a good target for the treatment of trypanosomiasis), with $\mathrm{IC}_{50}$ values of 650 and $180 \mu \mathrm{M}$, respectively. The glycolytic enzymes GAPDH are responsible for ATP production and have been reported to be vital for the survival of Trypanosomatids. ${ }^{140,141}$ From the stem bark of Vernonia guineensis (Asteraceae), vernoguinosterol (60) and vernoguinoside (61), exhibited interesting trypanocidal activity with $\mathrm{IC}_{50}$ values in the range $4.60-7.67 \mu \mathrm{M}^{142}$

\section{Other compound classes}

Other compound classes from AMP with reported activities on leishmaniasis and trypanosomiasis are shown in Figures 11 to 16, while a summary of the reported molecules is given in Table 3 (compounds 62 - 82).

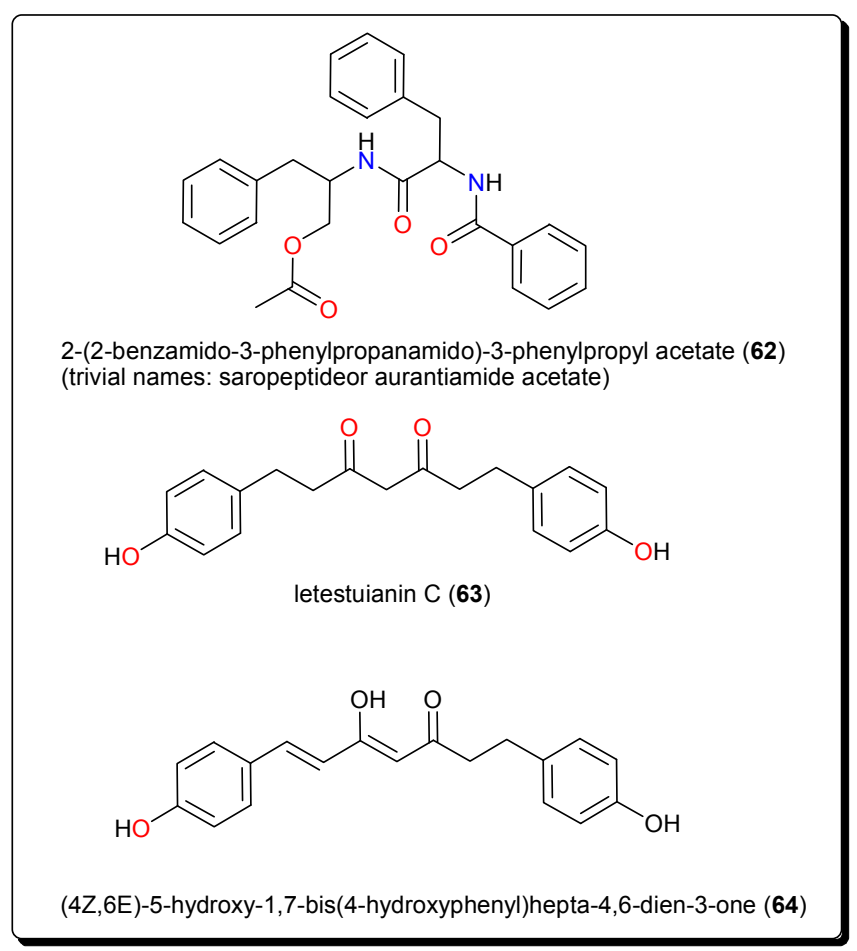

Fig. 11. An antitrypansomal amide and two diarylhepanoids.

\subsection{Amides}

Plants from the genus Zapoteca (Fabaceae) have been the origin of diverse compounds with antiprotozoal activities. These include the ester 2-(2-benzamido-3-phenylpropanamido)-3phenylpropyl acetate (trivial names; saropeptide or aurantiamide acetate) (62) from $Z$. portoricensis (Figure 11). ${ }^{143}$ The $\mathrm{IC}_{50}$ values of compound 62 were $3.63,41.65$ and $92.05 \mu \mathrm{M}$ against $T . b$. rhodesiense, T. cruzi and L6 cells, respectively. The compound had been previously reported to possess anti-inflammatory as well as antiplatelet aggregation activities, which are complementary to the observed trypanocidal property. ${ }^{144-148}$ Since inflammation poses major problems in the advanced stages of trypanosomiasis, compound $\mathbf{6 2}$ represents a promising natural hit with a reasonable selectivity for $T$. $b$. rhodesiense.

\subsection{Diarylhepanoids}

Other potent antitrypanosomal compounds are the diarylheptanoid; letestuianin $\mathrm{C}(63)$ and $(4 Z, 6 E)$-5-hydroxy-1,7bis(4-hydroxyphenyl)hepta-4,6-dien-3-one (64) from the species Aframomum letestuianum, Figure $12 . .^{130}$ The activities of 
Table 3: Other bioactive compounds from African flora with potential for antitrypanosomal and antileischmanial drug discovery.

\begin{tabular}{|c|c|c|c|c|c|c|c|c|}
\hline $\begin{array}{l}\text { Compound } \\
\text { number }\end{array}$ & $\begin{array}{l}\text { Compound class / } \\
\text { Subclass }\end{array}$ & $\begin{array}{l}\text { Part of plant } \\
\text { studied }\end{array}$ & Species name & Plant family & Place of collection & Used traditionally/locally & $\begin{array}{l}\text { Reported activity } \\
\text { on/against }\end{array}$ & Ref. \\
\hline 62 & Peptide & Roots & $\begin{array}{l}\text { Zapoteca } \\
\text { portoricensis }\end{array}$ & Fabaceae & $\begin{array}{l}\text { Nsukka, in Enugu } \\
\text { State, Nigeria }\end{array}$ & $\begin{array}{l}\text { in wound healing as well as the } \\
\text { treatment of toothache, tonsilitis, } \\
\text { against diarrhoea, and as an } \\
\text { anticonvulsant and antispasmodic }\end{array}$ & Trypanosomiasis & 143 \\
\hline 63,64 & Diarylheptanoid & Seeds & $\begin{array}{l}\text { Aframomum } \\
\text { letestuianum }\end{array}$ & Zingiberaceae & $\begin{array}{l}\text { Abong-bang, } \\
\text { Cameroon }\end{array}$ & $\begin{array}{l}\text { in addition to their spiritual belief } \\
\text { from the plant species, they are as well } \\
\text { used as food spice, and for the treatment } \\
\text { of inflammation, eczema, fevers, } \\
\text { laxative, anti-helmintic, mumps, etc. }\end{array}$ & Trypanosomiasis & 130 \\
\hline $65-68$ & Benzophenone & Fruits & $\begin{array}{l}\text { Allanblackia } \\
\text { monticola }\end{array}$ & $\begin{array}{l}\text { Clusiaceae } \\
\text { (Guttiferae) }\end{array}$ & $\begin{array}{l}\text { Bazou, West Province, } \\
\text { Cameroon }\end{array}$ & $\begin{array}{l}\text { treatment of certain human ailments } \\
\text { such as respiratory infections, diarrhoea, } \\
\text { toothache, pain, fever }\end{array}$ & Leishmanosomiasis & 149 \\
\hline 69 & Xanthone & Leaves & $\begin{array}{l}\text { Symphonia } \\
\text { globulifera }\end{array}$ & $\begin{array}{l}\text { Clusiaceae } \\
\text { (Guttiferae) }\end{array}$ & $\begin{array}{l}\text { Bangangté, West } \\
\text { Province, Cameroon }\end{array}$ & $\begin{array}{l}\text { to treat malaria, stomach and skin aches. } \\
\text { It is also used as laxative by pregnant } \\
\text { women and as a general tonic. }\end{array}$ & Leishmanosomiasis & 149 \\
\hline $70-72$ & Taccalonolide & Tubers & $\begin{array}{l}\text { Tacca } \\
\text { leontopetaloides }\end{array}$ & Taccaceae & Benue State, Nigeria & $\begin{array}{l}\text { tubers are also processed for food as } \\
\text { well as to treat stomach disorders, } \\
\text { gastric ulcers, tooth ache, high blood } \\
\text { pressure, hepatitis, enteritis and sexual } \\
\text { dysfunction }\end{array}$ & Trypanosomiasis & 156 \\
\hline $73-75$ & Quinone / Anthrone & Leaf latex & Aloe calidophila & Asphodelaceae & $\begin{array}{l}\text { Yabello and Mega, } \\
\text { Ethiopia }\end{array}$ & $\begin{array}{l}\text { to treat sexually transmitted infections, } \\
\text { digestive disorder, dermatological } \\
\text { ailments, opthalmia, conjunctivitis, } \\
\text { wounds, burns, other injuries, etc. }\end{array}$ & Leishmanosomiasis & 157 \\
\hline 76,77 & $\begin{array}{l}\text { Quinone / } \\
\text { Naphthoquinone }\end{array}$ & Seeds & $\begin{array}{l}\text { Triphyophyllum } \\
\text { peltatum }\end{array}$ & Dioncophyllaceae & $\begin{array}{c}\text { Parc de Taï, Ivory } \\
\text { Coast }\end{array}$ & $\begin{array}{l}\text { for treatment of malaria, dysentery and } \\
\text { elephantiasis }\end{array}$ & Leishmanosomiasis & 158 \\
\hline 78 & Lactone & Stems & Uvaria klainean & Annonaceae & $\begin{array}{l}\text { Forêt des Abeilles, } \\
\text { Gabon }\end{array}$ & $\begin{array}{l}\text { for treatment of skin diseases, parasitic } \\
\text { infections }\end{array}$ & Leishmanosomiasis & 159 \\
\hline 79 & & Leaves & Vitex simplicifolia & Verbenaceae & Nsukka, Nigeria & $\begin{array}{l}\text { to treat edema, gout, malaria, skin } \\
\text { diseases, toothache and dermatitis }\end{array}$ & Trypanosomiasis & 160 \\
\hline 80 & Flavonoid & Aerial parts & $\begin{array}{l}\text { Ageratum } \\
\text { conyzoides }\end{array}$ & $\begin{array}{l}\text { Asteraceae } \\
\text { (Compositae) }\end{array}$ & $\begin{array}{l}\text { Nile bank, Khartoum, } \\
\text { Sudan }\end{array}$ & $\begin{array}{l}\text { to treat leprosy, skin diseases, wound } \\
\text { healing, mental headaches, dyspnea and } \\
\text { infectious diseases. It is also used } \\
\text { locally for its anti-asthmatic, } \\
\text { antispasmodic, haemostatic effects and } \\
\text { as an oil lotion for purulent ophthalmia. }\end{array}$ & $\begin{array}{l}\text { Trypanosomiasis } \\
\text { and } \\
\text { leishmanosomiasis }\end{array}$ & 166 \\
\hline 81,82 & Phytosterol & Stem bark & Allexis cauliflora & Violaceae & Ebolowa, Cameroon & to treat fever and syphilis & Trypanosomiasis & 167 \\
\hline
\end{tabular}


compounds $63(4.49 \mu \mathrm{M})$ and $\mathbf{6 4}(8.39 \mu \mathrm{M})$ validate the use of the Aframomum sp. in treating parasitic ailments amongst others.

\subsection{Benzophenones and xanthones}

Guttiferone A (65), garcinol (66), cambogin (67) and guttiferone F (68) from Allanblackia monticola (Guttiferae or Clusiaceae) fruits and xanthone $\mathrm{V}_{1}$ (69) from Symphonia globulifera leaves have shown antileishmanial activities (Figure 12). ${ }^{149}$ The compounds exhibited very potent in vitro antileishmanial activities, particularly compounds 65 to 67 , with $\mathrm{IC}_{50}$ values of $0.16,0.33$ and $0.2 \mu \mathrm{M}$, for compounds $\mathbf{6 5}, \mathbf{6 6}$ and 67, respectively, which were lower than that of the reference drug, miltefosine $(0.46 \mu \mathrm{M})$. SAR studies could further improve the activities of these compounds in order to enhance their selectivity indices against human cancer cell lines.

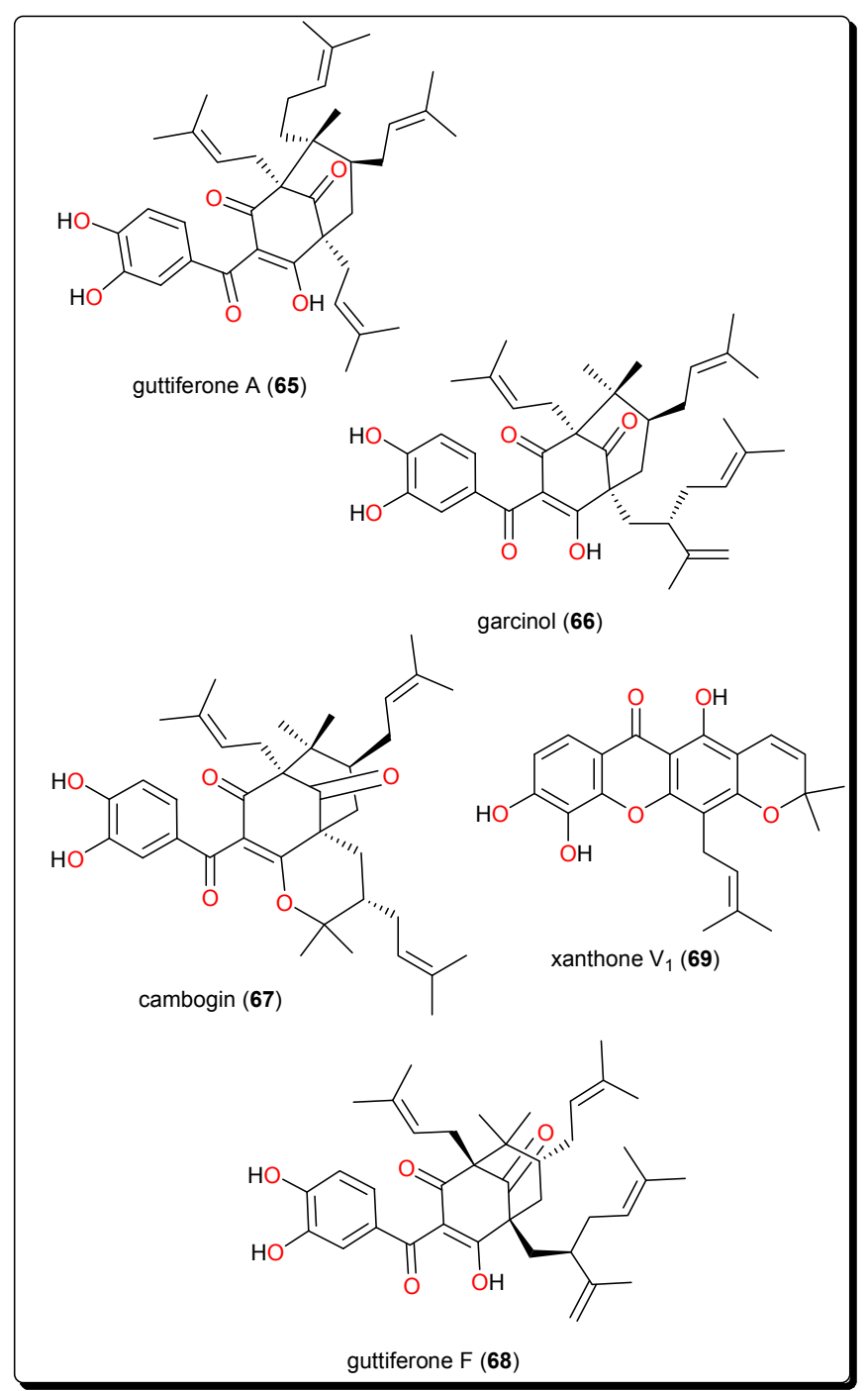

Fig. 12. Benzophenones and a xanthone with very potent in vitro antileishmanial activities in the nanomolar range.

\subsection{Taccalonolides}

Beside their proven anticancer potential, these represent a quite potent class of antitrypanosomal compounds identified from Tacca leontopetaloides (Taccaceae). ${ }^{150-155}$ These include taccalonolide A 12-propanoate (70), taccalonolide $\mathrm{T}$ (71) and taccalonolide S (72) from the tubers of T. leontopetaloide (Figure 13). They have shown activities against the T. b. brucei $\mathrm{s} 427$ lister strain. ${ }^{156}$ These compounds and crude fractions yielded $\mathrm{EC}_{50}$ values as low as $0.79 \mu \mathrm{g} / \mathrm{mL}$.

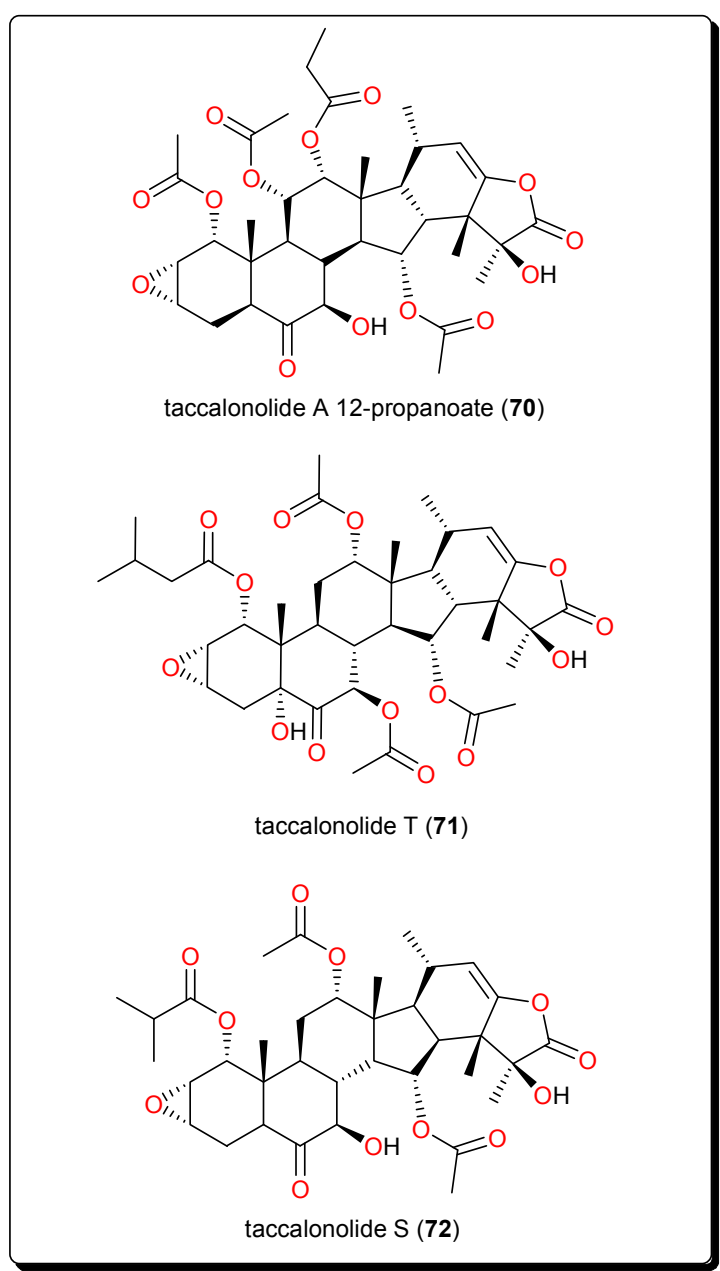

Fig. 13. Taccalonolides, a rare class of antiprotozoals.

\subsection{Quiniones and klaivanolide}

Quinones from Aloe species have also shown antileishmanial activities. These include aloinoside (73), aloin (74) and microdontin (75) from the leaf latex of $A$. calidophila (Figure 14). ${ }^{157}$ It is noteworthy that, the activities of the most potent compounds, with $\mathrm{IC}_{50}$ values ranging from 3.12 to $10.92 \mu \mathrm{M}$ against Leishmania aethiopica and from 3.70 to $15.26 \mu \mathrm{M}$ against Leishmania major, were comparable to the control drug amphotericin $\mathrm{B}\left(\mathrm{IC}_{50}=0.12\right.$ and $0.073 \mu \mathrm{M}$ against $L$. aethiopica and $L$. major respectively). The selectivity indices of aloinoside (73) (813.35 and 694.90, respectively, against L. aethiopica and L. major) were much better than those of the control, amphotericin B (423.49 and 688.96). This suggests that the isolated compounds could serve as potential scaffolds for the development of safe, specific and cost-effective antileishmanial agents. ${ }^{157}$ Additionally, the dioncoquinones A (76) and B (77) isolated from Triphyophyllum peltatum (Dioncophyllaceae) showed good and specific activity against $L$. major by inhibiting the growth of the parasite at very low concentrations. ${ }^{158}$ Klaivanolide (78), from the stems of Uvaria klaineana (Annonaceae), was also reported as a potent molecule (in vitro $\mathrm{IC}_{50}$ values of 1.75 and $3.12 \mathrm{mM}$, respectively) against sensitive and amphotericin B-resistant promastigote forms of $L$. donovani. ${ }^{159}$ 


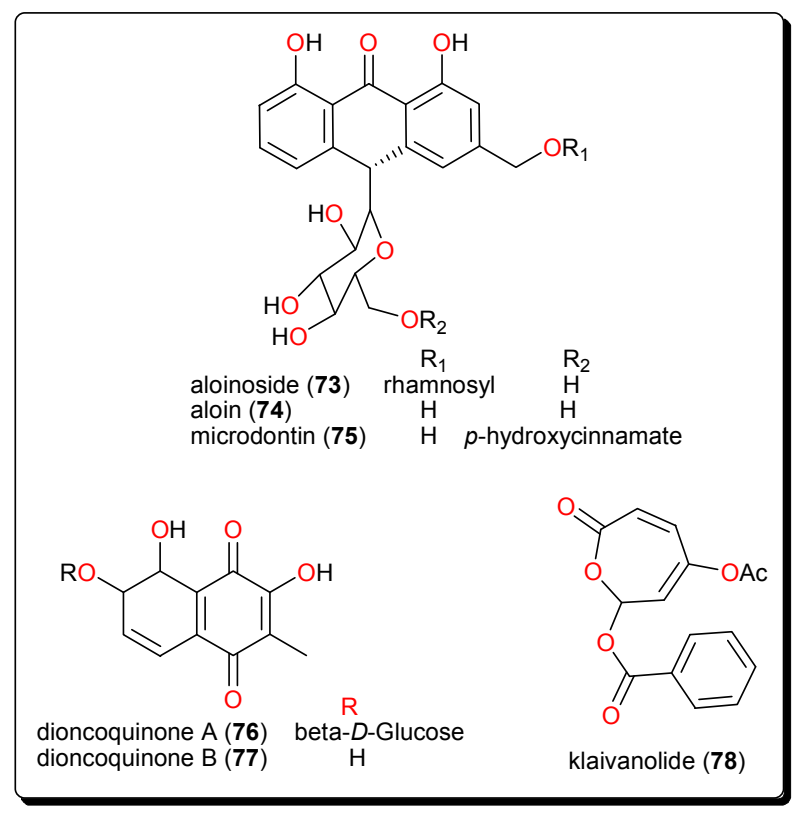

Fig. 14. Quiniones and klaivanolide, which showed lower micromolar activities against against several Leishmania species.

\subsection{Flavonoids}

Artemetin (79, Figure 15), from Vitex simplicifolia (Verbenaceae) leaves, exhibited promising trypanocidal activity with an $\mathrm{IC}_{50}$ value of $4.7 \mu \mathrm{g} / \mathrm{ml}$ and a selectivity index of 9.8 against rat skeletal myoblast cell line (L6 cells). ${ }^{160}$ While this activity confirms the use of this plant in the traditional treatment of ailments including parasitic diseases, ${ }^{161-163}$ phytochemical evaluation of trypanocidal activities was not reported before. Hence, the plant could further be investigated for the unidentified compounds. An investigation of Ageratum conyzoides (Asteraceae), a plant known for its importance in the treatment of sleeping sickness patients traditionally, ${ }_{164-166}$ led to the isolation of several flavonoids; 5,6,7,8,5'-pentamethoxy-3',4'methylenedioxyflavone (trivial name: eupalestin), 5,6,7,5'tetramethoxy-3',4'-methylenedioxyflavone, $5,6,7,8,3^{\prime}, 4^{\prime}, 5^{\prime}-$ heptamethoxy-flavone (trivial name: 5'-methoxynobiletine), 5,6,7,3',4',5'-hexamethoxy-flavone and 4'-hydroxy-5,6,7,3',5'pentamethoxyflavone (trivial name: ageconyflavone $\mathrm{C}, \mathbf{8 0}$ ) which displayed antiprotozoal activities, some in the lower micromolar range. ${ }^{166}$ Among the tested NPs, compound 80 showed the highest activity against $T$. b. rhodesiense and $L$. donovani with IC $_{50}$ values of 7.8 and $9.2 \mu \mathrm{M}$ respectively. However, all the isolated compounds showed an activity weaker than that of the crude extract, implying that the activities of the compounds in the mixture could be synergistic.

\subsection{Phytosterols}

22-hydroxyclerosterol (81) and clerosterol (82), Figure 15, were isolated from the stem bark of Allexis cauliflora (Violaceae). ${ }^{167}$ These compounds were evaluated for trypanocidal activities, and the activity of compound $\mathbf{8 1}\left(\mathrm{ED}_{50} 1.12 \mu \mathrm{M}\right)$ was far better than that of compound $82\left(\mathrm{ED}_{50} 134.34 \mu \mathrm{M}\right)$. These results prompted an investigation of their cytotoxic activities. It was observed that compound $\mathbf{8 1}$ inhibited mammalian cells at quite a similar concentration ( $\left.\mathrm{ED}_{50} 1.56 \mu \mathrm{M}\right)$, while compound 82 had no effect. This difference in activity could be attributed to the presence of the hydroxyl group at C-22 in the side chain of compound $\mathbf{8 1}$ which is absent in compound 82. Additionally, it was observed that compound $\mathbf{8 1}$ was more active and selective on the parasite enzyme glycolytic enzymes (PGI and GAPDH), when compared with compound $\mathbf{8 2}$.

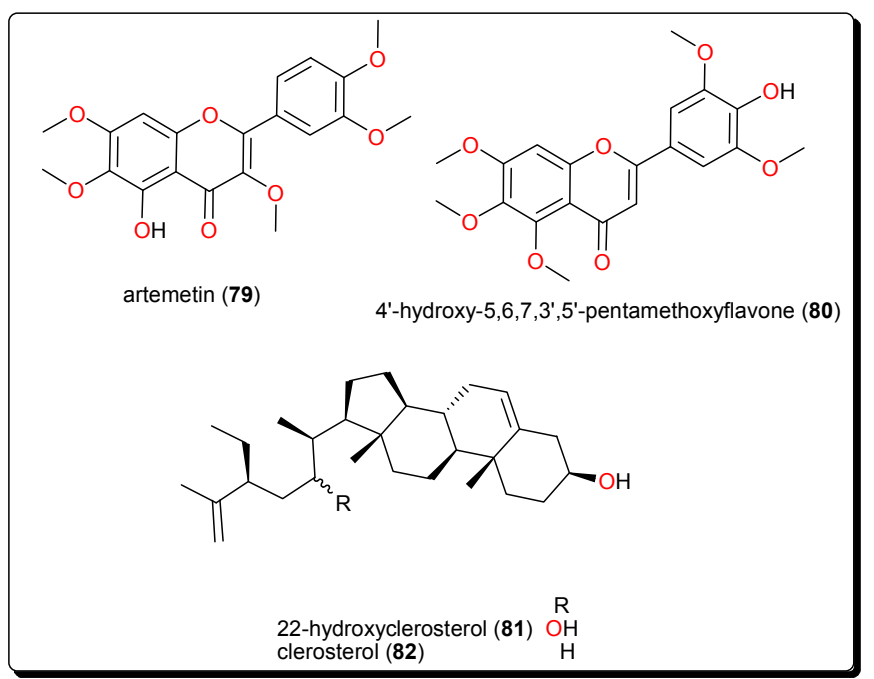

Fig. 15. Flavonoids and phytosterols with trypanocidal activities.

\section{Conclusions}

Parasitic diseases continue to represent a menace on a global scale and require attention due to lack of vaccines and reported resistance against available drugs for their treatment. This review focuses on different natural compounds and scaffolds that could lead drug discovery research groups into reasonable starting points for further development of fast, effective and affordable novel molecules for the treatment of parasitic diseases. Drug discovery and development now place efforts on the search for new moieties or chemical scaffolds of natural/semisynthetic origin and in the development of phytomedicines. As a means to facilitate accessibility of information, our research team has as one of its goals, to develop free online natural products libraries from African flora (http://african-compounds.org/). In this paper, an attempt has been made to draw together original research works on natural products from AMP with micromolar range activities against Schistosoma, Trypanosoma and Leishmania species. The compounds presented herein have demonstrated a diverse range of activities against different forms of trypanosomiasis, schistosomiasis and leishmaniasis, with some scaffolds and molecules showing great potential as starting points for further development into drugs. We recently collected a dataset of several hundred bioactive plant based metabolites from AMPs with activities against Trypanosoma sp. (Afrotryp) ${ }^{68} \mathrm{It}$ becomes interesting to perform in silico prediction of binding modes and binding free energy calculations of some of the compounds against some selected targets.

\section{Acknowledgments}

CVS is currently a Ph.D. student funded by the German Academic Exchange Services (DAAD). FNK currently holds a Georg Forster postdoctoral fellowship from the Alexander von Humboldt Foundation, Germany.

\section{Conflict of interest}

The authors declare no conflict of interest 


\section{References}

1. Mansueto P, Seidita A, Vitale G, Cascio A. Leishmaniasis in travelers: A literature review. Travel Med Infect Dis. 2014;12(6):563-581.

2. Lee BY, Bacon KM, Bottazzi ME, Hotez PJ. Global economic burden of Chagas disease: a computational simulation model. Lancet Infec Dis. 2013;13(4):342348.

3. Wells TNC, Alonso PL, Gutteridge WE. New medicines to improve control and contribute to the eradication of malaria. Nat Rev Drug Discov. 2009;8(11):879-891.

4. Ntie-Kang F, Onguéné PA, Lifongo LL, Ndom JC, Sippl W, Mbaze LM. The potential of anti-malarial compounds derived from African medicinal plants, part II: a pharmacological evaluation of non-alkaloids and non-terpenoids. Malar J. 2014;13:81.

5. Carmo M, Nunes P, Dones W, Morillo CA, Encina JJ, Ribeiro AL, Horizonte B. Chagas Disease: an overview of clinical and epidemiological aspects. $\mathrm{J}$ Am Coll Cardiol. 2013;62(9):767-776.

6. Kennedy PGE. Clinical features, diagnosis, and treatment of human African trypanosomiasis (sleeping sickness). Lancet Neurology. 2013;12:186-194.

7. de Vries H, Wagelmans APM, Hasker E, Lumbala C, Lutumba P, de Vlas SJ, Klundert J van de. Forecasting human african trypanosomiasis prevalences from population screening data using continuous time models. Funk S. PLOS Comput Bio. $2016 ; 12(9)$ :e1005103.

8. Copeland NK, Aronson NE. Leishmaniasis: treatment updates and clinical practice guidelines review. Curr Opi Infec Dis. 2015;28(5):426-437.

9. Colley DG, Bustinduy AL, Evan Secor W, King CH. Human schistosomiasis. Lancet. 2014;383(9936):22532264.

10. Rollinson D, Knopp S, Levitz S, Stothard JR, Tchuem Tchuenté L-A, Garba A, Mohammed KA, Schur N, Person B, Colley DG, Utzinger J. Time to set the agenda for schistosomiasis elimination. Acta Trop. 2013; 128(2):423-440.

11. Zouré HG, Noma M, Tekle AH, Amazigo UV, Diggle PJ, Giorgi E, Remme JH. The geographic distribution of onchocerciasis in the 20 participating countries of the African programme for onchocerciasis control: (2) precontrol endemicity levels and estimated number infected. Parasit Vectors. 2014;7(1):326.

12. Noma M, Zouré HG, Tekle AH, Enyong PA, Nwoke $\mathrm{BE}$, Remme JH. The geographic distribution of onchocerciasis in the 20 participating countries of the African programme for onchocerciasis control: (1) priority areas for ivermectin treatment. Parasit Vectors. 2014;7(1):325.

13. World Health Organization (WHO). World Malaria report 2017; Available from:

http:/www.who.int/malaria/publications/world-malariareport-2017/report/en/ 2017. Accessed: 10 January 2018.

14. Gray DJ, Ross AG, Li Y-S, Mcmanus DP. Clinical review diagnosis and management of schistosomiasis. Br Med J. 2011;342:d2651.

15. Olotu A, Fegan G, Wambua J, Nyangweso G, Leach A, Lievens M, Kaslow DC, Njuguna P, Marsh K., Bejon P. Seven-Year Efficacy of RTS,S/AS01 malaria vaccine among young african children. $N$ Engl $\mathrm{J} \mathrm{Med.}$ 2016;374(26):2519-2529.

16. Ntege EH, Arisue N, Ito D, Hasegawa T, Palacpac NMQ, Egwang TG, Horii T, Takashima E, Tsuboi T. Identification of Plasmodium falciparum reticulocyte binding protein homologue 5 -interacting protein, PfRipr, as a highly conserved blood-stage malaria vaccine candidate. Vaccine. 2016;34(46):5612-5622.

17. Lyke KE, Ishizuka AS, Berry AA, Chakravarty S, DeZure A, Enama ME, James ER, Billingsley PF, Gunasekera A, Manoj A, Li M, Ruben AJ, Li T, Eappen AG, Stafford RE, Kc N, Murshedkar T, Mendoza FH, Gordon IJ, Zephir KL, Holman LA, Plummer SH, Hendel CS, Novik L, Costner PJM, Saunders JG, Berkowitz NM, Flynn BJ, Nason MC, Garver LS, Laurens MB, Plowe CV, Richie TL, Graham BS, Roederer M, Sim BKL, Ledgerwood JE, Hoffman SL, Seder RA. Attenuated PfSPZ Vaccine induces straintranscending $\mathrm{T}$ cells and durable protection against heterologous controlled human malaria infection. Proc Natl Acad Sci USA. 2017;114(10):2711-2716.

18. Hanboonkunupakarn B, White NJ. The threat of antimalarial drug resistance. Trop Dis Travel Med Vaccines. 2016;2(1):10.

19. Blasco B, Leroy D, Fidock DA. Antimalarial drug resistance: linking Plasmodium falciparum parasite biology to the clinic. Nat Med. 2017;23(8):917-928.

20. Webster JP, Molyneux DH, Hotez PJ, Fenwick A. The contribution of mass drug administration to global health: past, present and future. Philos Trans R Soc B. 2014;369:20130434.

21. Doenhoff MJ, Kusel JR, Coles GC, Cioli D.Resistance of Schistosoma mansoni to praziquantel: is there a problem? Trans R Soc Trop Med Hyg. 2002;96(5):465469.

22. Heimburg T, Chakrabarti A, Lancelot J, Marek M, Melesina J, Hauser AT, Shaik TB, Duclaud S, Robaa D, Erdmann F, Schmidt M, Romier C, Pierce RJ, Jung M, Sippl W. Structure-Based Design and Synthesis of Novel Inhibitors Targeting HDAC8 from Schistosoma mansoni for the Treatment of Schistosomiasis. J Med Chem. 2016;59(6): 2423-2435.

23. Ismail M, Botros S, Metwally A, William S, Farghally A, Tao L-F, Day TA, Bennett JL. Resistance to praziquantel: direct evidence from Schistosoma mansoni isolated from Egyptian villagers. Am J Trop Med H. 1999;60(6):932-935.

24. Doenhoff MJ, Cioli D, Utzinger J. Praziquantel: mechanisms of action, resistance and new derivatives for schistosomiasis. Curr Opi Infec Dis. 2008;21(6):659-667.

25. Sparg SG, Van Staden J, Jäger AK. Efficiency of traditionally used South African plants against schistosomiasis. J Ethnopharmacol. 2000;73(1-2):209214.

26. Stolfa DA, Marek M, Lancelot J, Hauser A-T, Walter A, Leproult E, Melesina J, Rumpf T, Wurtz J-M, Cavarelli J, Sippl W, Pierce RJ, Romier C, Jung M. 2014. Molecular basis for the antiparasitic activity of a mercaptoacetamide derivative that inhibits histone deacetylase 8 (hdac8) from the human pathogen Schistosoma mansoni. J Mol Bio. 2014;426(20):34423453.

27. Andrews KT, Haque A, Jones MK. HDAC inhibitors in parasitic diseases. Immunol Cell Bio. 2012;90(1):66-77. 
28. Hotez PJ, Kamath A. Neglected Tropical Diseases in Sub-Saharan Africa: Review of Their Prevalence, Distribution, and Disease Burden. Cappello M. PLOS Negl Trop Dis. 2009;3(8):e412.

29. Brun R, Blum J, Chappuis F, Burri C. Human African trypanosomiasis. Lancet. 2010;375(9709):148-159.

30. World Health Organization (WHO). Chagas disease (American trypanosomiasis) Available from: http:/www.who.int/mediacentre/factsheets/fs340/en/ 2017. Accessed 9 November 2017.

31. World Health Organization (WHO). Trypanosomiasis, human African (sleeping sickness). Available from: http://www.who.int/mediacentre/factsheets/fs259/en/ 2017. Accessed 9 November 2017.

32. Simarro PP, Jannin J, Cattand P. Eliminating Human African Trypanosomiasis: Where Do We Stand and What Comes Next? PLOS Med. 2008;5(2):e55.

33. Aksoy S, Buscher P, Lehane M, Solano P, Van Den Abbeele J. Human African trypanosomiasis control: Achievements and challenges. Hotez PJ. PLOS Negl Trop Dis. 2017;11(4):e0005454.

34. Franco JR, Simarro PP, Diarra A, Ruiz-Postigo JA, Jannin JG. The journey towards elimination of gambiense human African trypanosomiasis: not far, nor easy. Parasitology. 2014;141(6):748-7 60.

35. Ready PD. Epidemiology of visceral leishmaniasis. $J$ Clin Epidemiol. 2014;6:147-154.

36. Aluru S, Hide M, Michel G, Bañuls A-L, Marty P, Pomares C. Multilocus microsatellite typing of Leishmania and clinical applications: a review. Parasite. 2015;22(V1):16.

37. World Health Organization (WHO). Leishmaniasis. Available from: http://www.who.int/mediacentre/factsheets/fs375/en/ 2017. Accessed: 9 November 2017

38. Martins-Melo FR, Lima M da S, Ramos AN, Alencar $\mathrm{CH}$, Heukelbach J. Mortality and case fatality due to visceral leishmaniasis in Brazil: A nationwide analysis of epidemiology, Trends and Spatial Patterns. Schallig HDFH, editor. PLoS One. 2014;9(4):e93770.

39. Einzig A, Hochster H, Wiernik P, Trump D, Dutcher J, Garowski E, Sasloff J, Smith T. A phase II study of taxol in patients with malignant melanoma. Invest New Drugs. 1991;9(1):59-64.

40. Wani MC, Taylor HL, Wall ME, Coggon P, McPhail AT. Plant antitumor agents. VI. Isolation and structure of taxol, a novel antileukemic and antitumor agent from Taxus brevifolia. J Am Chem Soc. 1971;93(9):23252327.

41. Rishton GM. Natural products as a robust source of new drugs and drug leads: Past successes and present day issues. Am J Cardiol. 2008;101(10):S43-49.

42. Phillipson JD. Phytochemistry and medicinal plants. Phytochemistry. 2001;56(3):237-243.

43. Cordell GA. Phytochemistry and traditional medicineThe revolution continues. Phytochem Lett. 2014; 10:xxviii-xl.

44. Ntie-Kang F, Lifongo LL, Simoben CV, Babiaka SB, Sippl W, Mbaze LM. The uniqueness and therapeutic value of natural products from West African medicinal plants, part I: uniqueness and chemotaxonomy. RSC Adv. 2014;4(67):28728-28755.

45. Ntie-Kang F, Lifongo LL, Simoben C V, Babiaka SB, Sippl W, Mbaze LM. The uniqueness and therapeutic value of natural products from West African medicinal plants, part II: terpenoids, geographical distribution and drug discovery. RSC Adv. 2014;4(67):35348-35370.

46. Simoben CV, Ntie-Kang F, Lifongo LL, Babiaka SB, Sippl W, Mbaze LM. The uniqueness and therapeutic value of natural products from West African medicinal plants, part III: least abundant compound classes. RSC Adv. 2014;4(67):40095-40110.

47. Tietjen I, Ntie-Kang F, Mwimanzi P, Onguéné PA, Scull MA, Idowu TO, Ogundaini AO, Meva'a LM, Abegaz BM, Rice CM, Andrae-Marobela K, Brockman MA, Brumme ZL, Fedida D. Screening of the panAfrican natural product library identifies ixoratannin A2 and boldine as novel HIV-1 inhibitors. PLoS One. 2015;10(4):e0121099.

48. Newman DJ, Cragg GM, Snader KM. The influence of natural products upon drug discovery. Nat Prod Rep. 2000;17(3):215-234.

49. van Wyk BE. A broad review of commercially important southern African medicinal plants. $J$ Ethnopharmacol. 2008;119(3):342-355.

50. Harvey AL, Edrada-Ebel R, Quinn RJ. The reemergence of natural products for drug discovery in the genomics era. Nat Rev Drug Discov. 2015;14(2):111129.

51. Ibrahim MA, Mohammed A, Isah MB, Aliyu AB. Antitrypanosomal activity of African medicinal plants: A review update. J Ethnopharmacol. 2014;154(1):26-54.

52. Ntie-Kang F, Lifongo LL, Mbaze LM, Ekwelle N, Owono Owono LC, Megnassan E, Judson PN, Sippl W, Efange SMN. Cameroonian medicinal plants: a bioactivity versus ethnobotanical survey and chemotaxonomic classification. BMC Complement Altern Med. 2013;13(1):147.

53. Lifongo LL, Simoben CV, Ntie-Kang F, Babiaka SB, Judson PN. A Bioactivity Versus Ethnobotanical Survey of Medicinal Plants from Nigeria, West Africa. Nat Prod and Bioprospect. 2014;4(1):1-19.

54. Ntie-Kang F, Zofou D, Babiaka SB, Meudom R, Scharfe M, Lifongo LL, Mbah JA, Mbaze LM, Sippl W, Efange SMN. AfroDb: a select highly potent and diverse natural product library from African medicinal plants. PLoS One, 2013;(10): e78085.

55. Adamu HM, Abayeh OJ, Agho MO, Abdullahi AL, Uba A, Dukku HU, Wufem BM. An ethnobotanical survey of Bauchi State herbal plants and their antimicrobial activity. J Ethnopharmacol. 2005;99(1):1-4.

56. Magassouba FB, Diallo A, Kouyaté M, Mara F, Mara O, Bangoura O, Camara A, Traoré S., Diallo AK, Zaoro M, Lamah K, Diallo S, Camara G, Traoré S, Kéita A, Camara MK, Barry R, Kéita S, Oularé K, Barry MS, Donzo M, Camara K, Toté K, Berghe D Vanden, Totté J, Pieters L, Vlietinck AJ, Baldé AM. Ethnobotanical survey and antibacterial activity of some plants used in Guinean traditional medicine. J Ethnopharmacol. 2007;114(1):44-53.

57. Brendler T, van Wyk BE. A historical, scientific and commercial perspective on the medicinal use of Pelargonium sidoides (Geraniaceae). $J$ Ethnopharmacol. 2008;119(3):420-433.

58. Dike IP, Obembe OO, Adebiyi FE. Ethnobotanical survey for potential anti-malarial plants in southwestern Nigeria. J Ethnopharmacol. 2012;144(3):618626.

59. Kambizi L, Afolayan A. An ethnobotanical study of plants used for the treatment of sexually transmitted 
diseases (njovhera) in Guruve District, Zimbabwe. $J$ Ethnopharmacol. 2001;77(1):5-9.

60. Abo KA, Fred-Jaiyesimi AA, Jaiyesimi AEA. Ethnobotanical studies of medicinal plants used in the management of diabetes mellitus in South Western Nigeria. J Ethnopharmacol. 2008;115(1):67-71.

61. Ashidi JS, Houghton PJ, Hylands PJ, Efferth T. Ethnobotanical survey and cytotoxicity testing of plants of South-western Nigeria used to treat cancer, with isolation of cytotoxic constituents from Cajanus cajan Millsp. leaves. J Ethnopharmacol. 2010;128(2):501512.

62. Semenya S, Potgieter M, Erasmus L. Ethnobotanical survey of medicinal plants used by Bapedi healers to treat diabetes mellitus in the Limpopo Province, South Africa. J Ethnopharmacol. 2012;141(1):440-445.

63. Maregesi SM, Ngassapa OD, Pieters L, Vlietinck AJ. Ethnopharmacological survey of the Bunda district, Tanzania: Plants used to treat infectious diseases. $J$ Ethnopharmacol. 2007;113(3):457-470.

64. World Health Organization (WHO). Available from: Facts sheet http://www.who.int/mediacentre/news/releases/2004/pr 44/en/ 2004. Accessed 7 January 2017.

65. Vonthron-Sénécheau C, Weniger B, Ouattara M, Bi FT, Kamenan A, Lobstein A, Brun R, Anton R. In vitro antiplasmodial activity and cytotoxicity of ethnobotanically selected Ivorian plants. $J$ Ethnopharmacol. $2003 ; 87(2-3): 221-5$.

66. Jansen O, Angenot L, Tits M, Nicolas JP, De Mol P, Sacre PY, Jonville MC, Frederich M. In vitro antiplasmodial activity of ethnobotanically selected plants from Burkina Faso. Planta Med. 2008;74(9):1142.

67. Mbaya AW, Ibrahim UI. In vivo and in vitro activities of medicinal plants on haemic and humoral trypanosomes: A review. Int J Pharmacol. 2011;7:111.

68. Ibezim A, Debnath B, Ntie-Kang F, Mbah CJ, Nwodo NJ. Binding of anti-Trypanosoma natural products from African flora against selected drug targets: a docking study. Med Chem Res. 2017; 26:562-579

69. Nwodo NJ, Ibezim A, Ntie-Kang F, Adikwu MU, Mbah CJ. Anti-Trypanosomal activity of Nigerian plants and their constituents. Molecules. 2015;20(5):7750-7771

70. Hoet S, Opperdoes F, Brun R, Quetin-Leclercq J. Natural products active against African trypanosomes: A step towards new drugs. Nat Prod Rep. 2004;21: 353-364.

71. Ogungbe, I.V.; Setzer, W.N. Comparative molecular docking of antitrypanosomal natural products into multiple Trypanosoma brucei drug targets. Molecules. 2009;14:1513-1536.

72. Schmidt TJ, Khalid SA, Romanha AJ, Alves TMA, Biavatti MW, Brun R, Da Costa FB, de Castro SL, Ferreira VF, de Lacerda MVG, et al. The potential of secondary metabolites from plants as drugs or leads against protozoan neglected diseases part I. Curr Med Chem. 2012;19:2128-2175.

73. Schmidt TJ, Khalid SA, Romanha AJ, Alves TMA, Biavatti MW, Brun R, Da Costa FB, de Castro SL, Ferreira VF, de Lacerda MVG, et al. The potential of secondary metabolites from plants as drugs or leads against protozoan neglected diseases part II. Curr Med Chem. 2012;19:2176-2228.
74. Ntie-Kang F, Telukunta KK, Döring K, Simoben CV., Moumbock AFA, Malange YI, Njume LE, Yong JN, Sippl W, Günther S. NANPDB: A Resource for Natural Products from Northern African Sources. J Nat Prod. 2017;80(7):2067-2076.

75. Ntie-Kang F. An in silico evaluation of the ADMET profile of the StreptomeDB database. SpringerPlus. 2013;2:353.

76. Inada A, Ogasawara R, Koga I, Nakatani N, Inatomi Y, Murata H, Nishi M, Nakanishi T. Three new furoquinoline alkaloids from the leaves of Boninia glabra. Chem Pharm. Bull. . 2008;56(5):727-729.

77. Devkota KP, Wansi JD, Lenta BN, Khan S, Choudhary MI, Sewald N. Bioactive steroidal alkaloids from Sarcococca hookeriana. Planta Med. 2010;76(10):1022-1025.

78. Cheesman L, Nair JJ, Van Staden J. Antibacterial activity of crinane alkaloids from Boophone disticha (Amaryllidaceae). J Ethnopharmacol. 2012;140(2):405-408.

79. Mishra BB, Kale RR, Singh RK, Tiwari VK. Alkaloids: Future prospective to combat leishmaniasis. Fitoterapia. 2009;80(2):81-90.

80. Tsassi BV, Hussain H, Geagni A, Dongo E, Ahmed I, Riaz M, et al. Citropremide and citropridone: A new ceramide and a new acridone alkaloid from the stem bark of Citropsis gabunensis. Hel Chim Acta, 2011;94(6):1035-40.

81. Ndagijimana A, Wang X, Pan G, Zhang F, Feng H, Olaleye O. A review on indole alkaloids isolated from Uncaria rhynchophylla and their pharmacological studies. Fitoterapia, 2013;86(1):35-47.

82. Nnadi CO, Nwodo NJ, Kaiser M, Brun R, Schmidt TJ, Steroid alkaloids from Holarrhena africana with strong activity against Trypanosoma brucei rhodesiense. Molecules. 2017;22(7):1129.

83. Uzor PF, Ebrahim W, Osadebe PO, Nwodo JN, Okoye FB, Müller WEG, Lin W, Liu Z, Proksch P. Metabolites from Combretum dolichopetalum and its associated endophytic fungus nigrospora oryzae-evidence for a metabolic partnership. Fitoterapia. 2015;105:147-150.

84. Okoye TC, Akah PA, Ezike AC, Uzor PF, Odoh UE, Igboeme SO, Onwuka UB, Okafor SN. Immunomodulatory effects of Stachytarpheta cayennensis leaf extract and its synergistic effect with artesunate. BMC Complement Altern Med. 2014;14(1):376.

85. Bringmann G, Dreyer M, Faber JH, Dalsgaard PW, Stærk D, Jaroszewski JW, Ndangalasi H, Mbago F, Brun R, Christensen SB. Ancistrotanzanine C and related 5,1'- and 7,3'-coupled naphthylisoquinoline alkaloids from Ancistrocladus tanzaniensis. J Nat Prod. 2004;67(5):743-748.

86. Bringmann G, Dreyer M, Faber JH, Dalsgaard PW, Staerk D, Jaroszewski JW, Ndangalasi H, Mbago F, Brun R, Reichert M, Maksimenka K, Christensen SB. Ancistrotanzanine A, the first 5,3'-coupled naphthylisoquinoline alkaloid, and two further, 5,8'linked related compounds from the newly described species Ancistrocladus tanzaniensis. J Nat Prod. 2003;66(9):1159-65.

87. Bringmann G, Hamm A, Günther C, Michel M, Brun R, Mudogo V. Ancistroealaines A and B, two new bioactive naphthylisoquinolines, and related naphthoic acids from Ancistrocladus ealaensis. J Nat Prod. 2000;63(11):1465-1470. 
88. Bringmann G, Messer K, Brun R, Mudogo V. Ancistrocongolines A-D, new naphthylisoquinoline alkaloids from Ancistrocladus congolensis. J Nat Prod. 2002;65(8):1096-101.

89. Bringmann G, Kajahn I, Reichert M, Pedersen SEH, Faber JH, Gulder T, Brun R, Christensen SB, PonteSucre A, Moll H, Heubl G, Mudogo V. Ancistrocladinium A and B, the First N,C-coupled naphthyldihydroisoquinoline alkaloids, from a Congolese Ancistrocladus Species. J Org Chem. 2006;71:9348-9356.

90. Bringmann G, Saeb W, Rukert M, Mies J, Michel M, Mudogo V, Brun R. Ancistrolikokine D, a 5,8'-coupled naphthylisoquinoline alkaloid, and related natural products from Ancistrocladus likoko. Phytochemistry. 2003;62:631-636.

91. Bringmann G, Messer K, Wolf K, Mühlbacher J, Grüne M, Brun R, Louis AM. Dioncophylline E from Dioncophyllum thollonii, the first 7,3'-coupled dioncophyllaceous naphthylisoquinoline alkaloid. Phytochemistry. 2002;60(4):389-397.

92. Bringmann G, Dreyer M, Michel M, Tayman FSK, Brun R. Ancistroheynine B and two further 7,3'coupled naphthylisoquinoline alkaloids from Ancistrocladus heyneanus Wall. Phytochemistry, 2004;65(21):2903-2907.

93. Ngemenya MJ, Hanna JN, Komtchou JA, Efange SMN. In vitro screening of 1-aryl-6-hydroxy-1,2,3,4tetrahydroisoquinolines: Structure related activity against pathogenic bacteria. Asian Pac J Trop Biomed. 2015;5(6):472-477.

94. Hanna JN, Ntie-Kang F, Kaiser M, Brun R, Efange SMN. 1-Aryl-1,2,3,4-tetrahydroisoquinolines as potential antimalarials: synthesis, in vitro antiplasmodial activity and in silico pharmacokinetics evaluation. RSC Adv. 2014;4(44):22856-22865.

95. Hoet S, Stévigny C, Block S, Opperdoes F, Colson P, Baldeyrou B, Lansiaux A, Bailly C, Quetin-Leclercq J. Alkaloids from Cassytha filiformis and related aporphines: Antitrypanosomal activity, cytotoxicity, and interaction with DNA and topoisomerases. Planta Med. 2004;70(5):407-413.

96. Montenegro H, Gutiérrez M, Romero LI, Ortega-Barría E, Capson TL, Rios LC. Aporphine alkaloids from Guatteria spp. with leishmanicidal activity. Planta Med. 2003;69(7):677-679.

97. Atawodi SE, Ameh DA, Ibrahim S, Andrew JN, Nzelibe HC, Onyike EO, Anigo KM, Abu EA, James DB, Njoku GC, Sallau AB. Indigenous knowledge system for treatment of trypanosomiasis in Kaduna State of Nigeria. J Ethnopharmacol. 2002;79(2):279_ 282.

98. Cretton S, Breant L, Pourrez L, Ambuehl C, Marcourt L, Ebrahimi SN, Hamburger M, Perozzo R, Karimou S, Kaiser M, Cuendet M, Christen P. Antitrypanosomal quinoline alkaloids from the roots of Waltheria indica. J Nat Prod. 2014;77(10):2304-2311.

99. Abubakar MS, Musa AM, Ahmed A, Hussaini IM. The perception and practice of traditional medicine in the treatment of cancers and inflammations by the Hausa and Fulani tribes of Northern Nigeria. $J$ Ethnopharmacol. 2007;111(3):625-629.

100. Olowokudejo JD, Kadiri AB, Travih VA. An Ethnobotanical Survey of Herbal Markets and Medicinal Plants in Lagos State of Nigeria. Ethnobot Leafl. 2008;12:851-865.
101. Maregesi SM, Ngassapa OD, Pieters L, Vlietinck AJ. Ethnopharmacological survey of the Bunda district, Tanzania: Plants used to treat infectious diseases. $J$ Ethnopharmacol. 2007;113:457-470.

102. Soladoye MO, Adetayo MO, Chukwuma EC, Adetunji AN. Ethnobotanical Survey of Plants Used in the Treatment of Haemorrhoids in South-Western Nigeria. Ann Biol Res. 2010;1(4):1-15.

103. de Wet H, Nkwanyana MN, van Vuuren SF. Medicinal plants used for the treatment of diarrhoea in northern Maputaland, KwaZulu-Natal Province, South Africa. $J$ Ethnopharmacol. 2010;130(2):284-289.

104. Tekle AH, Zouré HGM, Noma M, Boussinesq M, Coffeng LE, Stolk WA, Remme JHF. Progress towards onchocerciasis elimination in the participating countries of the african programme for onchocerciasis control: epidemiological evaluation results. Infect Dis Poverty. 2016;5(1):66

105. Buske A, Kekule AS, Haring A, Adam G. Medicaments containing tetrahydroisoquinoline derivatives. Google Patents, Pergamon Press. 2003. p. WO2003000272 A1. Available from:

https:/www.google.com/patents/WO2003000272A1?cl $=$ en

106. Ngantchou I, Nyasse B, Denier C, Blonski C, Hannaert V, Schneider B, Blonski C. Antitrypanosomal alkaloids from Polyalthia suaveolens (Annonaceae): Their effects on three selected glycolytic enzymes of Trypanosoma brucei. Bioorg Med Chem Lett. 2010;20:3495-3498.

107. Leandro LM, de Sousa Vargas F, Barbosa PCS, Neves JKO, da Silva JA, da Veiga-Junior VF. Chemistry and Biological Activities of Terpenoids from Copaiba (Copaifera spp.) Oleoresins. Molecules. 2012;17(12):3866-3889.

108. Thoppil RJ, Bishayee A. Terpenoids as potential chemopreventive and therapeutic agents in liver cancer. World J Hepatol. 2011;3(9):228-249.

109. Achenbach H, Schwinn A. Aporphinoid Alkaloids and Terpenoids From Piptostigma fugax. Phytochemistry. 1995;38(4):1037-1048.

110. Nkunya MHH. Unusual metabolites from some Tanzanian indigenous plant species. Pure and Appl Chem. 2005;77(11):1943-1955.

111. Nakano K, Yoshida C, Furukawa W, Takaishi Y, Shishido K. Terpenoids in transformed root culture of Tripterygium wilfordii. Phytochemistry. 1998;49(6):1821-1824.

112. Onguéné PA, Ntie-Kang F, Lifongo LL, Ndom JC, Sippl W, Mbaze LM. The potential of anti-malarial compounds derived from African medicinal plants, part I: a pharmacological evaluation of alkaloids and terpenoids. Malar J. 2013;12(1):449.

113. Faiella L, Temraz A, Siciliano T, De Tommasi N, Braca A. Terpenoids from the leaves of Podocarpus gracilior. Phytochemistry Lett. 2012;5(2):297-300.

114. Nwodo JN, Ibezim A, Simoben CV, Ntie-Kang F. Exploring cancer therapeutics with natural products from African medicinal plants, part II: alkaloids, terpenoids and flavonoids. Anticancer Agents Med Chem. 2016;16(1):108-127.

115. Wube A, Bucar F, Gibbons S, Asres K, Rattray L, Croft S. Antiprotozoal activity of drimane and coloratane sesquiterpenes towards Trypanosoma brucei rhodesiense and Plasmodium falciparum In vitro. Phytother Res. 2010;24:1468-1472. 
116. Olila D, Opuda-Asibo J, Olwa-Odyek. Bioassay-guided studies on the cytotoxic and in vitro trypanocidal activities of a sesquiterpene (Muzigadial) derived from a Ugandan medicinal plant (Warburgia ugandensis). Afr Heal Sci. 2001;1(1):12-15.

117. Kokwaro JO. Medicinal plants of East Africa. 3rd ed. Kokwaro JO, editor. Kampala, Nairobi, Dar-EsSalaam,: University of Nairobi Press. 2009:215.

118. Machumi F, Yenesew A, Midiwo JO, Heydenreich M, Kleinpeter E, Tekwani BL, Khan SI, Walker LA, Muhammad I. Antiparasitic and anticancer carvotacetone derivatives of Sphaeranthus bullatus. Nat Prod Commun. 2012;7(9):1123-1126.

119. Ragasa C, Tsai P-W, Galvez C, Shen C-C. New Carvotanacetone Derivatives from Sphaeranthus africanus. Planta Med. 2010;76(2):146-151.

120. Jakupovic J, Grenz M, Bohlmann F, Mungal GM. Carvotacetone derivatives and eudesman-12,63-olides from Sphaeranthus species. Phytochemistry. 1990;29(4):1213-1217.

121. Machumi F, Samoylenko V, Yenesew A, Derese S, Midiwo JO, Wiggers FT, Jacob MR, Tekwani BL, Khan SI, Walker LA, Muhammad I. Antimicrobial and antiparasitic abietane diterpenoids from the roots of Clerodendrum eriophyllum. Nat Prod Commun. 2010;5(6):853-858.

122. Ebiloma GU, Igoli JO, Katsoulis E, Donachie AM, Eze A, Gray AI, de Koning HP. Bioassay-guided isolation of active principles from Nigerian medicinal plants identifies new trypanocides with low toxicity and no cross-resistance to diamidines and arsenicals. $J$ Ethnopharmacol. 2017;202:256-264.

123. Aliyu AB, Musa AM, Abdullahi MS, Oyewale AO, Gwarzo US. Activity of plant extracts used in Northern Nigerian traditional medicine against methicillinresistant Staphylococcus aureus (Mrsa). Niger J Pharm Res. 2008;7(1):1-8.

124. Nyasse B, Ngantchou I, Tchana EM, Sonké B, Denier $\mathrm{C}$, Fontaine $\mathrm{C}$, Nyasse B. Inhibition of both Trypanosoma brucei bloodstream form and related glycolytic enzymes by a new kolavic acid derivative isolated from Entada abyssinica. Pharmazie. 2004;59:873-875.

125. Freiburghaus F, Ogwal EN, Nkunya MHH, Kaminsky $\mathrm{R}$, Brun R. In vitro antitrypanosomal activity of African plants used in traditional medicine in Uganda to treat sleeping sickness. Trop Med Int Health. 1996;1:765771.

126. Soh D, Nkwengoua E, Ngantchou I, Nyasse B, Denier C, Hannaert V, Shaker KH, Schneider B. Xylopioxyde and other bioactive kaurane-diterpenes from Xylopia aethiopica Dunal (Annonaceae). J Appl Pharm Sci. 2013;3:13-19.

127. Tane P, Tatsimo SD, Ayimele GA, Connolly JD. Bioactive metabolites from Aframomum species. In: 11th NAPRECA Symposium Book of Proceedings, Antananarivo, Madagascar, 2005:214-223.

128. Cheikh-Ali Z, Okpekon T, Roblot F, Bories C, Cardao M, Jullian JC, Poupon E, Champy P. Labdane diterpenoids from Aframomum sceptrum: NMR study and antiparasitic activities. Phytochem Lett. 2011;4(3):240-244.

129. Okpekon T, Yolou S, Gleye C, Roblot F, Loiseau P, Bories C, Grellier P, Frappier F, Laurens A, Hocquemiller R. Antiparasitic activities of medicinal plants used in Ivory Coast. J Ethnopharmacol. 2004;90(1):91-97.

130. Kamnaing P, Tsopmo A, Tanifum EA, Tchuendem MHK, Tane P, Ayafor JF, Sterner O, Rattendi D, Iwu MM, Schuster B, Bacchi C. Trypanocidal diarylheptanoids from Aframomum letestuianum. J Nat Prod. 2003;66:364-367.

131. El-Seedi HR, El-Shabasy R, Sakr H, Zayed M, El-Said AMA, Helmy KMH, Gaara AHM, Turki Z, Azeem M, Ahmed AM, Boulos L, Borg-Karlson A-K, Göransson U. Anti-schistosomiasis triterpene glycoside from the Egyptian medicinal plant Asparagus stipularis. Revista Brasileira de Farmacognosia (Brazilian J Pharmacog.) 2012;22(2):314-318.

132. Boulos L. Medicinal Plants of North Africa. Reference Publications, Inc., Algonac, Michigan, USA. 1983:130.

133. Maregesi SM, Hermans N, Dhooghe L, Cimanga K, Ferreira D, Pannecouque C, Berghe DA Vanden Cos P, Maes L, Vlietinck AJ, Apers S, Pieters L.

Phytochemical and biological investigations of Elaeodendron schlechteranum. J Ethnopharmacol. 2010;129(3):319-326.

134. Maregesi SM, Pieters L, Ngassapa OD, Apers S, Vingerhoets R, Cos P, Vanden Berghe DA, Vlietinck AJ. Screening of some Tanzanian medicinal plants from Bunda district for antibacterial, antifungal and antiviral activities. J Ethnopharmacol. 2008;119:58-66.

135. Thiem DA, Sneden AT, Khan SI, Tekwani BL. Bisnortriterpenes from Salacia madagascariensis. J Nat Prod. 2005;68(2):251-254.

136. Bero J, Hannaert V, Chataigné G, Hérent MF, QuetinLeclercq J. In vitro antitrypanosomal and antileishmanial activity of plants used in Benin in traditional medicine and bio-guided fractionation of the most active extract. J Ethnopharmacol. 2011;137(2) :998-1002.

137. Bero J, Ganfon H, Jonville MC, Frédérich M, Gbaguidi F, DeMol P, Moudachirou M, Quetin-Leclercq J. In vitro antiplasmodial activity of plants used in Benin in traditional medicine to treat malaria. J Ethnopharmacol. 2009;122(3):439-444.

138. Bero J, Beaufay C, Hannaert V, Hérent MF, Michels PA, Quetin-Leclercq J. Antitrypanosomal compounds from the essential oil and extracts of Keetia leucantha leaves with inhibitor activity on Trypanosoma brucei glyceraldehyde-3-phosphate dehydrogenase. Phytomedicine. 2013;20(3-4):270-274.

139. Ngantchou I, Nkwengoua E, Nganso Y, Nyasse B, Denier C, Hannaert V, Schneider B. Antitrypanosomal activity of polycarpol from Piptostigma preussi (Annonaceae). Fitoterapia. 2009;80(3)188-191.

140. Hannaert V, Opperdoes FR, Michels PAM. Glycosomal Glyceraldehyde-3-phosphate dehydrogenase of Trypanosoma brucei and Trypanosoma cruzi: expression in Escherichia coli, purification, and characterization of the enzymes. Protein Expr Purif. 1995;6(3):244-250.

141. Nyasse B, Nono JJ, Nganso Y, Ngantchou I, Schneider B. Uapaca genus (Euphorbiaceae), a good source of betulinic acid. Fitoterapia. 2009;80(1):32-34.

142. Tchinda AT, Tsopmo A, Tane P, Ayafor JF, Connolly JD, Sterner O. Vernoguinosterol and vernoguinoside, trypanocidal stigmastane derivatives from Vernonia guineensis (Asteraceae). Phytochemistry. 2002;59(4):371-4. 
143. Nwodo NJ, Okoye FBC, Lai D, Debbab A, Brun R, Proksch P. Two trypanocidal dipeptides from the roots of Zapoteca portoricensis (fabaceae). Molecules. 2014;19(5):5470-5477.

144. Kuo P-C, Hwang T-L, Lin Y-T, Kuo Y-C, Leu Y-L. Chemical Constituents from Lobelia chinensis and their anti-virus and anti-inflammatory bioactivities. Arch Pharm Res. 2011;34(5):715-722.

145. Catalán CAN, de Heluani CS, Kotowicz C, Gedris TE, Herz W. A linear sesterterpene, two squalene derivatives and two peptide derivatives from Croton hieronymi. Phytochemistry. 2003;64(2):625-629.

146. Nwagwu M, Inyang AL, Molokwu RI, Essien EM. Platelet-aggregating activity of released factor(s) from Trypanosoma brucei brucei. Afr J Med Med Sci. 1989;18(4):283-7.

147. Lundkvist GBS, Sellix MT, Nygård M, Davis E, Straume M, Kristensson K, Block GD. Clock Gene Expression during chronic inflammation induced by infection with Trypanosoma brucei brucei in Rats. $J$ of Biol Rhythms. 2010;25(2):92-102.

148. Kuete V. Efferth T. Pharmacogenomics of Cameroonian traditional herbal medicine for cancer therapy. J Ethnopharmacol. 2011;137(1):752-766.

149. Lenta BN, Vonthron-Sénécheau C, Weniger B, Devkota KP, Ngoupayo J, Kaiser M, Naz Q, Choudhary MI, Tsamo E, Sewald N. Leishmanicidal and cholinesterase inhibiting activities of phenolic compounds from Allanblackia monticola and Symphonia globulifera. Molecules. 2007;12(8):1548-1557.

150. Jiang J, Yang H, Wang Y, Chen Y. Phytochemical and pharmacological studies of the genus Tacca: A Review. Trop J Pharm Res. 2014;13(4):635.

151. Ni G, Yang H-Z, Fu N-J, Zhang L-L, Wang M-C, Chen J, Zhang C-L, Li Y, Chen X-G, Chen R-Y, Yu D-Q. Cytotoxic Taccalonolides and Withanolides from Tacca chantrieri. Planta Med. 2015;81:247-256.

152. Akihito Yokosuka, Yoshihiro Mimaki, Hiroshi Sakagami, Sashida Y. New Diarylheptanoids and diarylheptanoid glucosides from the rhizomes of Tacca chantrieri and their cytotoxic activity. J Nat Prod. 2002;65(3):283-289.

153. Zhong-Liang C, Bao-De W, Min-Quin C. Study on the bitter principles from Tacca plants: Structures of taccalonolides A and B. Acta Chim Sin. 1988;6(3):2516.

154. Peng J, Risinger AL, Fest GA, Jackson EM, Helms G, Polin LA, Mooberry SL. Identification and Biological Activities of new taccalonolide microtubule stabilizers. J Med Chem. 2011;54(17):6117-6124.

155. Borokini TI, Ayodele AE. Phytochemical screening of Tacca Leontopetaloides (L.) Kuntze Collected from four geographical locations in Nigeria. Int J Mod Bot. 2012;2(4):97-102.

156. Dike VT, Vihiior B, Bosha JA, Yin TM, Ebiloma GU, de Koning HP, Igoli JO, Gray AI. Antitrypanosomal activity of a novel taccalonolide from the tubers of Tacca leontopetaloides. Phytochem Anal. 2016;27:217221.

157. Abeje F, Bisrat D, Hailu A, Asres K. Phytochemistry and antileishmanial activity of the leaf latex of Aloe calidophila Reynolds. Phytother Res. 2014;28(12):1801-1805.

158. Bringmann G, Rüdenauer S, Irmer A, Bruhn T, Brun R, Heimberger T, Stühmer T, Bargou R, Chatterjee M. Antitumoral and antileishmanial dioncoquinones and ancistroquinones from cell cultures of Triphyophyllum peltatum (Dioncophyllaceae) and Ancistrocladus abbreviatus (Ancistrocladaceae). Phytochemistry. 2008;69(13):2501-2509.

159. Akendengue B, Roblot F, Loiseau PM, Bories C, NgouMilama E, Laurens A, Hocquemiller R. Klaivanolide, an antiprotozoal lactone from Uvaria klaineana. Phytochemistry. 2002;59(8):885-888.

160. Nwodo N, Okoye F, Lai D, Debbab A, Kaiser M, Brun $\mathrm{R}$, Proksch P. Evaluation of the in vitro trypanocidal activity of methylated flavonoid constituents of Vitex simplicifolia leaves. BMC Complement Altern Med. 2015;15:82-86.

161. Liang F, XiangZhen Z, Lan C. Investigation report on Vitex trifolia L. var. simplicifolia Cham. medicinal plant resources in China. Med Plants. 2012;3(1):16-22.

162. Munir AA. A taxonomic revision of the genus Vitex L. (Verbenaceae) in Australia. J Adel Bot Gard. 1987;10(1):31-79.

163. Keay RWJ. Trees of Nigeria. Keay RWJ, editor. Clarendon Press; Revised, Subsequent edition. 1989:340-345.

164. Kamboj A, Saluja AK. Ageratum conyzoides L.: A review on its phytochemical and pharmacological profile. Int J Green Pharm. 2008;2(2):59-68.

165. Okunade AL. Ageratum conyzoides L. (Asteraceae). Fitoterapia. 2002;73(1):1-16.

166. Nour AMM, Khalid SA, Kaiser M, Brun R, Abdalla WE, Schmidt TJ. The antiprotozoal activity of methylated flavonoids from Ageratum conyzoides L. $J$ Ethnopharmacol. 2010;129(1):127-130.

167. Nganso YOD, Ngantchou IEW, Nkwenoua E, Nyasse B, Denier C, Hannert V, Schneider B. Antitrypanosomal and cytotoxic activities of 22hydroxyclerosterol, a new sterol from Allexis cauliflora (Violaceae). Sci Pharm. 2011;79:137-144.

Click here to remove instruction text... 